\title{
Ground-Water Storage Change and Land Subsidence in Tucson Basin and Avra Valley, Southeastern Arizona, 1998-2002
}

Prepared in cooperation with the

Arizona Department of Water Resources, Tucson Water, Pima County,

the Town of Oro Valley, and Metropolitan Domestic Water Improvement District

Scientific Investigations Report 2007-5275 
This page left intentionally blank. 


\section{Ground-Water Storage Change and Land Subsidence in Tucson Basin and Avra Valley, Southeastern Arizona, 1998-2002}

By Donald R. Pool and Mark T. Anderson

Prepared in cooperation with the

Arizona Department of Water Resources, Tucson Water, Pima County, the Town of Oro Valley, and Metropolitan Domestic Water Improvement District

Scientific Investigations Report 2007-5275 


\section{U.S. Department of the Interior DIRK KEMPTHORNE, Secretary}

\section{U.S. Geological Survey \\ Mark D. Myers, Director}

U.S. Geological Survey, Reston, Virginia: 2008

This report and any updates to it are available online at:

http://pubs.usgs.gov/sir/2008/5275,

For product and ordering information:

World Wide Web: http://www.usgs.gov/pubprod

Telephone: 1-888-ASK-USGS

For more information on the USGS - the Federal source for science about the Earth, its natural and living resources, natural hazards, and the environment:

World Wide Web: http://www.usgs.gov

Telephone: 1-888-ASK-USGS

Any use of trade, product, or firm names is for descriptive purposes only and does not imply endorsement by the U.S. Government.

Although this report is in the public domain, permission must be secured from the individual copyright owners to reproduce any copyrighted materials contained within this report.

Suggested citation:

Pool, D.R., and Anderson, M.A., 2008, Ground-water storage change and land subsidence in Tucson Basin and Avra Valley, southeastern Arizona, 1998-2002: U.S. Geological Survey Scientific Investigations Report 2007-5275, 34 p.

Cataloging-in-publication data are on file with the Library of Congress (http://www.loc.gov/). 


\section{Contents}

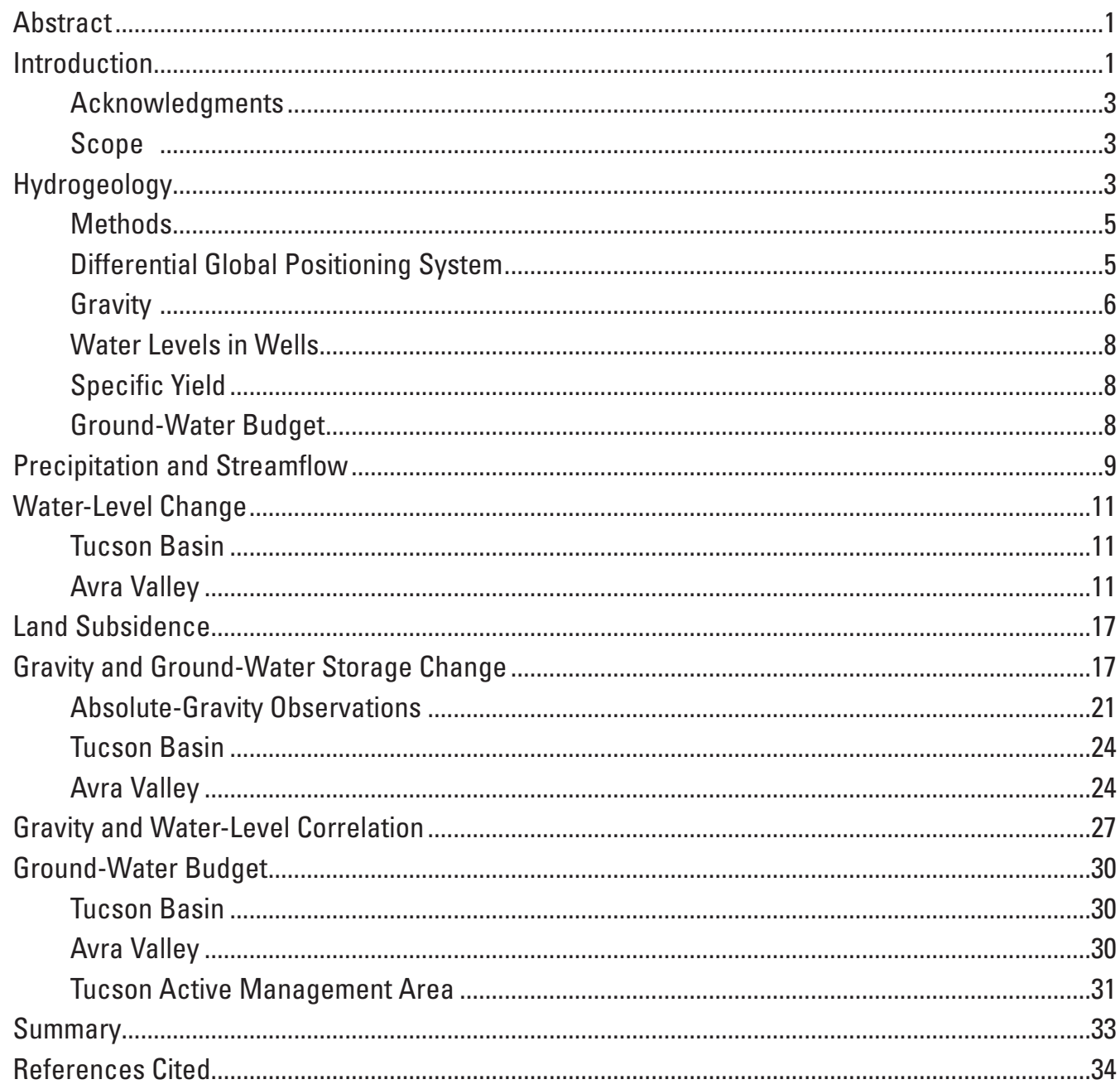

\section{Figures}

1. Study area and network of ground-water storage monitoring stations within the Tucson Active Management Area, Pima and Pinal Counties, Arizona ............................................2

2. Ground-water storage mechanisms within the Tucson Active Management Area, Pima and Pinal Counties, Arizona . .4

3. Photographs of gravity monitoring and Global Positioning System equipment............................6

4. Selected representations of common relations between hydraulic head, screened intervals, water levels in wells, and water tables in the Tucson Active Management Area.

5. Precipitation and streamflow at selected stations within the Tucson Active Management Area, 1997-2002.

6. Gravity and water-level change at ground-water storage monitoring stations within the Tucson Active Management Area winter 1998 to spring 1002

7. Water-level change in the Tucson Active Management Area. 
8. Land subsidence at wells and benchmarks within the Tucson Active Management Area, spring 1999 to spring 2002

9. Ground-water storage change in the Tucson Active Management Area ..................................25

10. Cumulative ground-water budget within the monitored portions of the

Tucson Active Management Area, winter 1998 to spring 2002

\section{Tables}

1. Positions of ground-water storage monitoring stations in the Tucson Active Management Area and change in ellipsoid height, 1998 to 2002

2. Correlation of gravity and water-level change and estimates of specific yield at wells in the Tucson Active Management Area, 1998 to 2002

3. Cumulative ground-water budgets for the monitored portions of the Tucson Basin, Avra Valley, and Tucson Active Management Area, 1998 to 2002. 


\section{Conversion Factors and Datum}

\begin{tabular}{lll}
\hline \multicolumn{1}{c}{ Multiply } & By & \multicolumn{1}{c}{ To obtain } \\
\hline centimeter $(\mathrm{cm})$ & 0.3937 & inch \\
meter $(\mathrm{m})$ & 3.281 & foot \\
kilometer $(\mathrm{km})$ & 0.6214 & mile \\
square meter $\left(\mathrm{m}^{2}\right)$ & 0.0002471 & acre \\
square kilometer $\left(\mathrm{km}^{2}\right)$ & 0.3861 & square mile \\
cubic hectometer $\left(\mathrm{hm}^{3}\right)$ & 810.7 & acre-foot \\
cubic hectometer per year $\left(\mathrm{hm}^{3} / \mathrm{yr}\right)$ & 811.03 & acre-foot per year \\
cubic meter per day $\left(\mathrm{m}^{3} / \mathrm{yr}\right)$ & 3.378 & acre-foot per year \\
cubic meter per second $\left(\mathrm{m}^{3} / \mathrm{s}\right)$ & 35.31 & cubic foot per second \\
square hectometer $\left(\mathrm{hm}^{2}\right)$ & 2.471 & acre \\
\hline
\end{tabular}

Vertical coordinate information is referenced to the North American Vertical Datum of 1988 (NAVD 88).

\section{Arizona Well-Numbering System}

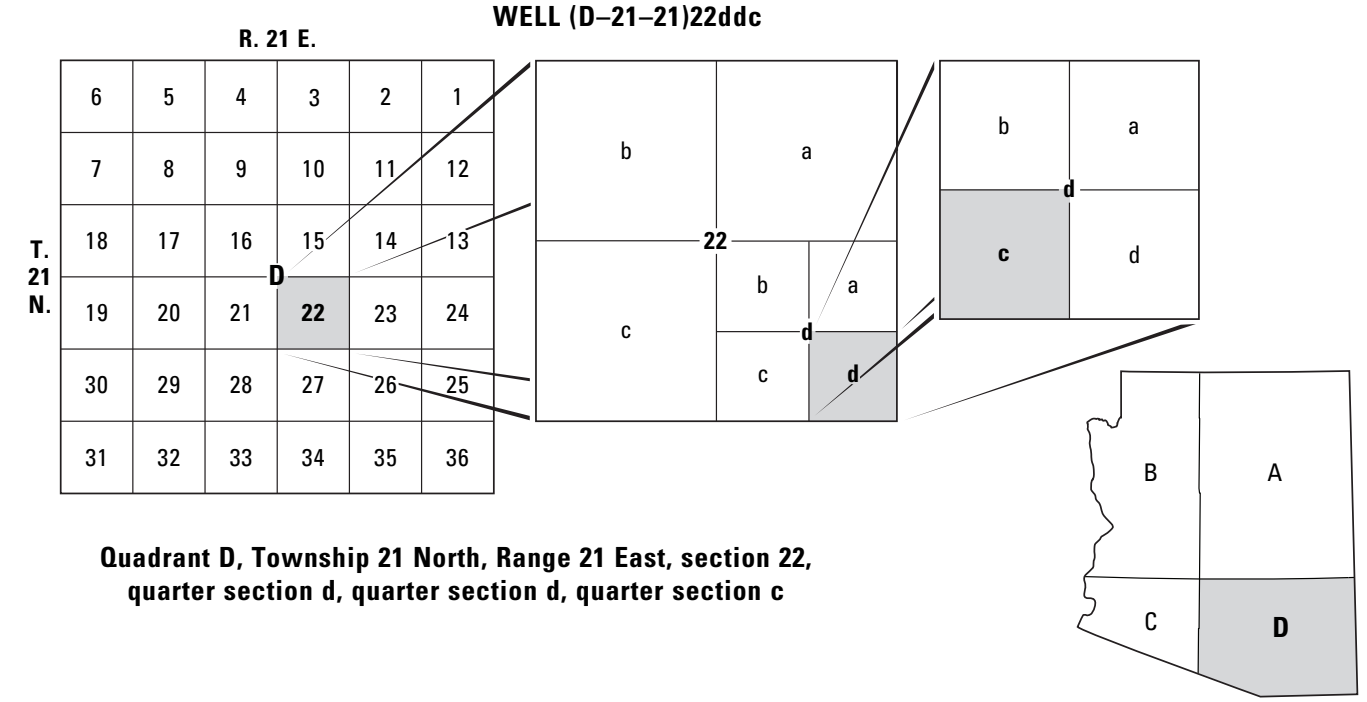

The well numbers used by the U.S. Geological Survey in Arizona are in accordance with the Bureau of Land Management's system of land subdivision. The land survey in Arizona is based on the Gila and Salt River meridian and base line, which divide the State into four quadrants and are designated by capital letters A, $\mathrm{B}, \mathrm{C}$, and $\mathrm{D}$ in a counterclockwise direction beginning in the northeast quarter. The first digit of a well number indicates the township, the second the range, and the third the section in which the well is situated. The lowercase letters a, b, c, and d after the section number indicate the well location within the section. The first letter denotes a particular 160-acre tract, the second the 40-acre tract, and the third the 10-acre tract. These letters are also assigned in a counterclockwise direction beginning in the northeast quarter. If the location is known within the 10-acre tract, three lowercase letters are shown in the well number. When more than one well is within a 10-acre tract, consecutive numbers beginning with 1 are added as suffixes. In the example shown, well number (D-21-21)22ddc designates the well as being in the SE1/4, SE1/4, SW1/4, section 22, Township 21 North, and Range 21 East. 
This page left intentionally blank. 


\title{
Ground-Water Storage Change and Land Subsidence in Tucson Basin and Avra Valley, Southeastern Arizona, 1998-2002
}

\author{
By Donald R. Pool and Mark T. Anderson
}

\section{Abstract}

Gravity and land subsidence were measured annually at wells and benchmarks within two networks in Tucson Basin and Avra Valley from 1998 to 2002. Both networks are within the Tucson Active Management Area. Annual estimates of ground-water storage change, ground-water budgets, and land subsidence were made based on the data. Additionally, estimates of specific yield were made at wells within the monitored region. Increases in gravity and water-level rises followed above-average natural recharge during winter 1998 in Tucson Basin. Overall declining gravity and water-level trends from 1999 to 2002 in Tucson Basin reflected general declining ground-water storage conditions and redistribution of the recent recharge throughout a larger region of the aquifer. The volume of stored ground-water in the monitored portion of Tucson Basin increased 200,000 acre-feet from December 1997 to February 1999; however, thereafter an imbalance in ground-water pumpage in excess of recharge led to a net storage loss for the monitoring period by February 2002. Ground-water storage in Avra Valley increased 70,000 acre-feet during the monitoring period, largely as a result of artificial and incidental recharge in the monitored region. The water-budget for the combined monitored regions of Tucson Basin and Avra Valley was dominated by about 460,000 acrefeet of recharge during 1998 followed by an average-annual recharge rate of about 80,000 acre-feet per year from1999 to 2002. Above-average recharge during winter 1998, followed by average-annual deficit conditions, resulted in an overall balanced water budget for the monitored period. Monitored variations in storage compared well with simulated averageannual conditions, except for above-average recharge from 1998 to 1999 . The difference in observed and simulated conditions indicate that ground-water flow models can be improved by including climate-related variations in recharge rates rather than invariable rates of average-annual recharge. Observed land-subsidence during the monitoring period was less than 1 inch except in the central part of Tucson Basin where land subsidence was about 2-3 inches.

Correlations of gravity-based storage and water-level change at 37 wells were variable and illustrate the complex nature of the aquifer system. Storage and water-level variations were insufficient to estimate specific yield at many wells. Correlations at several wells were poor, inverse, or resulted in unreasonably large values of specific yield. Causes of anomalously correlated gravity and water levels include significant storage change in thick unsaturated zones, especially near major ephemeral channels, and multiple aquifers that are poorly connected hydraulically. Good correlation of storage and water-level change at 10 wells that were not near major streams where significant changes in unsaturated zone storage occur resulted in an average specific-yield value of 0.27.

\section{Introduction}

Ground-water pumping in the Tucson Active Management Area (TAMA; fig. 1) has exceeded recharge for decades, thereby depleting water from aquifer storage. The TAMA encompasses most of Tucson Basin and Avra Valley within Pima County in southeastern Arizona and includes the metropolitan area of the City of Tucson and several other towns and agricultural areas. The regulatory goal under the Arizona Groundwater Management Act of 1980 is to create a balanced ground-water budget by the year 2025, where ground-water withdrawals are equal to recharge. In order to assess progress toward this goal, water managers in the TAMA need information about the primary ground-water budget components of inflow, outflow, and storage change. Improved ground-water budget information will reduce uncertainty and improve management of the ground-water resource by the Arizona Department of Water Resources (ADWR), private water providers, the municipalities of Tucson, Oro Valley, and Marana, and the Metropolitan Domestic Water Improvement District.

Some of the ground-water budget components can be measured directly, including the amount of water that is artificially recharged and withdrawals from wells that pump more than $35 \mathrm{gpm}$ - the Arizona Groundwater Management Act of 1980 mandates all wells that pump more than $35 \mathrm{gpm}$ be metered. Other components must be estimated by using indirect methods, including withdrawals by small capacity wells, evapotranspiration, ground-water underflow, incidental 


\section{Ground-Water Storage Change and Land Subsidence in Tucson Basin and Avra Valley, Southeastern Arizona, 1998-2002}

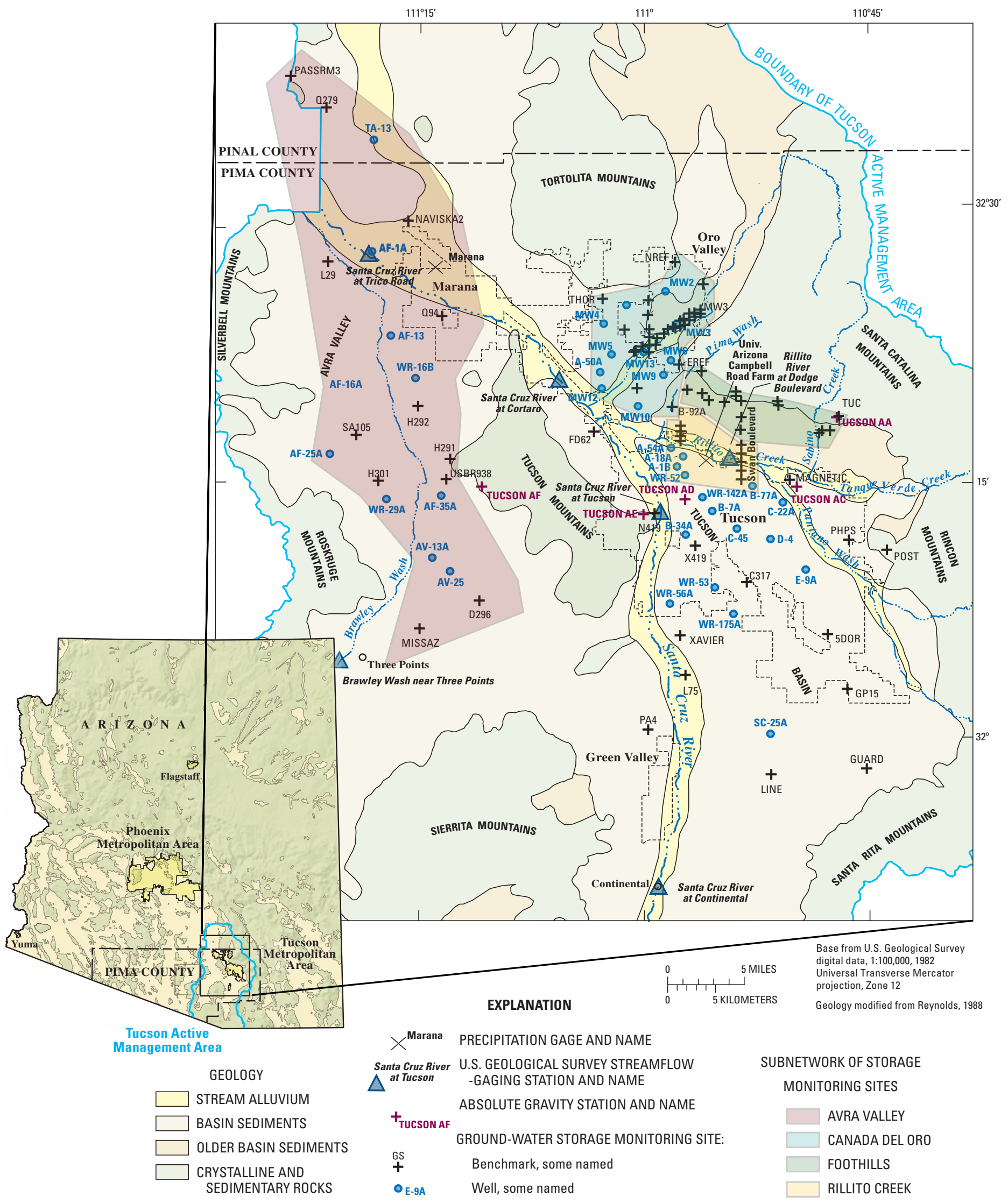

Figure 1. Study area and network of ground-water storage monitoring stations within the Tucson Active Management Area, Pima and Pinal Counties, Arizona. 
recharge from effluent recharge and other sources, and natural recharge from many sources. Estimation of several groundwater budget components results in large uncertainty in the ground-water budget. The greatest uncertainty can be attributed to a lack of information about natural recharge and groundwater storage change. Estimates of the natural recharge rates are highly uncertain and are dependent on accurate measurements of annual precipitation and streamflow, which have a high interannual variation (Pool, 2005). Estimates of ground-water storage change also are highly uncertain when computed as residuals in the water budget equations because the storage term includes the cumulative uncertainty of all other components.

Gravity methods can be used to measure ground-water storage change directly which reduces uncertainty in the ground-water budget by eliminating a large source of error. Land subsidence associated with declining water levels must be measured at monitoring stations to support the gravity methods. The land-subsidence information is used to estimate the portion of storage loss that results from compaction of pore space in the aquifer. Another benefit of using gravity methods is the ability to estimate the specific yield of the aquifer at monitoring sites where ground-water levels are measured. Specific yield is a measure of the volume of water that can be released from storage and is difficult to estimate by using other methods. Previous applications of gravity methods to estimate storage change were limited to small areas (Pool and Schmidt, 1997; Pool, 1999; Howle and others, 2003). In this report, the first results of estimating storage change for a large portion of a regional aquifer system are presented.

\section{Acknowledgments}

This investigation and report is the result of cooperation among several individuals and agencies. The Pima County Surveyors office organized and conducted the majority of the Global Positioning Surveys. The National Geodetic Survey of the National Oceanic and Atmospheric Administration conducted absolute-gravity surveys. Project development was aided by several other agencies, including, ADWR, Tucson Water, Metropolitan Domestic Water Improvement District, and the Town of Oro Valley.

This investigation builds upon several previous investigations. Dr. John Sumner of the University of Arizona Geosciences Department helped pioneer gravity methods for measuring ground-water storage change. The original subsidence and ground-water storage monitoring network in Tucson Basin was begun by Dr. John Sumner and students Kevin Cole, Ken Loy, and Mike Hatch in the late-1980s in cooperation with the National Geodetic Survey.

\section{Scope}

Ground-water-storage change and land subsidence were monitored in a portion of the TAMA on an approximately annual basis from December 1997 to May 2002. Data used in this report are combined from 5 networks of stations across large parts of the primary aquifer in Tucson Basin and Avra Valley (fig. 1). Monitoring at 128 stations in Tucson Basin includes data from 4 separate networks that were established for monitoring gravity and subsidence at varying temporal and spatial scales. A regional monitoring network of 35 stations was surveyed annually during December 1997 through May 2002. Seasonal monitoring of a network of 59 stations in the Lower Cañada del Oro Basin began in 1995 (Pool and others, 2000). A network of 19 stations near Rillito Creek was designed to monitor storage change and ephemeral-channel recharge beginning in 1998 (Pool, 2005). A network of 15 stations in the foothills of the Santa Catalina Mountains was designed to monitor seasonal variations in storage and mountain-front recharge beginning in 1999 (Stonestrom and others, 2008). Monitoring at 23 stations in Avra Valley was done as a single regional network that was surveyed once each year. Land subsidence was measured at least annually by using Global Positioning System (GPS) methods at the regional monitoring stations in Tucson Basin and Avra Valley. Many stations in each network were co-located at monitor wells where water levels were measured and specific yield was estimated. Annual storage change in Tucson Basin and Avra Valley was estimated by interpolation of gravity change across the area of each network. Water-budget estimates of natural recharge rates were made for the monitored regions in Tucson Basin and Avra Valley as a residual of estimated storage change, outflows, and other sources of inflow.

\section{Hydrogeology}

The primary aquifer materials in the TAMA are thick alluvial deposits that are bounded by crystalline rocks in the surrounding mountains. Water is stored in the pore spaces between grains of gravel, sand, silt, and clay in the alluvial deposits. Water is transmitted primarily through permeable pore spaces between grains of sand and gravel, but little transmission occurs through the poorly permeable pores between grains of silt and clay. Ground water enters the TAMA region as infiltration of streamflow in ephemeral streams and groundwater underflow along the southern and northern boundaries of the TAMA. Ground-water outflow primarily occurs through ground-water withdrawals from wells, but also occurs as ground-water outflow at the northwestern margin of the TAMA. Outflow from the ground-water flow system through evapotranspiration is minimal in comparison to other waterbudget components (Hanson and Benedict, 1994). Long-term ground-water withdrawal rates that are greater than recharge rates to the ground-water system have resulted in a reduction in ground-water storage and water-level declines during the last several decades. Short-term increases in storage and water levels also have occurred during periods of months to years after short-term increases in the volume of recharge following periods of above normal precipitation (Pool, 2005). 


\section{Ground-Water Storage Change and Land Subsidence in Tucson Basin and Avra Valley, Southeastern Arizona, 1998-2002}

The alluvial deposits are heterogeneous and include layers of poorly permeable silt and clay that are interbedded with highly permeable layers of gravel and sand. The silt and clay layers form aquitards that restrict the flow of water between adjacent aquifers of sand and gravel (fig. 2). The interbedded layers constitute part of an aquifer system that includes multiple aquifers that are generally hydraulically connected; however, thick aquitards impede the vertical flow of water between aquifers in places. Aquitards are common in the basin center, but also occur on the basin margins. Local perched aquifers occur in places above silt and clay layers that lie above the water table. Several local perched aquifers occur near major ephemeral streams where deep percolating water from streamflow infiltration is intercepted by silt and clay layers. Perched aquifers near ephemeral streams are often ephemeral. Perched aquifers develop following infiltration, but drain as the temporarily available water flows across the margin of silt and clay, or permeates through the deposit to the underlying unsaturated zone and aquifer.

Ground-water storage change occurs through three mechanisms in the study area, including (1) changes in the water content of pore spaces in the unsaturated zone, (2) changes in the volume of saturated pores in the regional aquifer system and in perched aquifers, and (3) expansion and contraction of saturated pore volume in compressible portions of the aquifer system (fig. 2). The focus of this investigation is only quantification of the aquifer storage-change portion of groundwater storage change. Changes in unsaturated-zone storage that are not transmitted to the aquifer system but evaporated from the soil and transpired by vegetation are unavailable for withdrawal except by vegetation. Water flows into and out of storage in pore spaces in the zone of water-table variation as water levels rise and fall, respectively. Water also flows in and out of storage with compression of the aquifer system through changes in the volume of the saturated pores. Most of the compressible storage change occurs in the most compressible parts of the aquifer system, which are intervals primarily composed of silt and clay-sized particles. Water is released from storage in compressible intervals as water levels decline in adjacent coarse-grained intervals. The amount of water released from storage is equivalent to the volume of pore-space compaction, which manifests as lowering of the land surface in a process known as land subsidence. Typically, very little water can return to storage in the compressible pores because compaction has permanently rearranged the silt and clay particles.

Changes in unsaturated-zone water storage are normally restricted to the root zone, except beneath ephemeral channels, where infiltration of concentrated runoff often exceeds

\section{Primary Ground-Water Storage Mechanisms in the Tucson Active Management Area}

Change in water content of pores with water-level decline and aquifer-system compaction

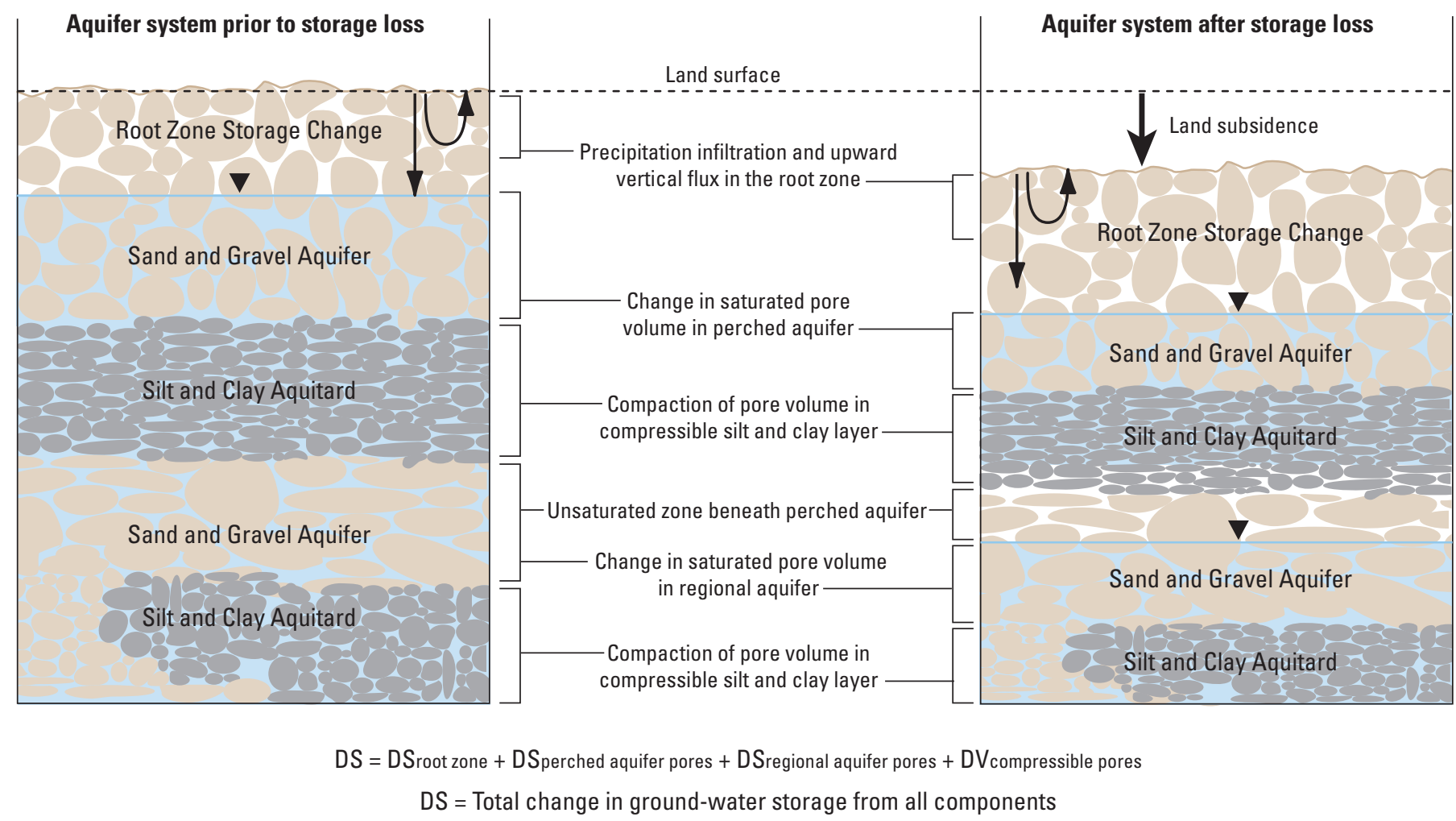

Figure 2. Ground-water storage mechanisms within the Tucson Active Management Area, Pima and Pinal Counties, Arizona. 
root-zone transpiration demands and results in deep percolation of infiltrated water and temporary changes in storage between the water table and the root zone. The thickness of the root zone varies from only a few feet in areas outside of stream channels to as much as $49 \mathrm{ft}$ near ephemeral-stream channels where phreatophytes, primarily mesquite, may tap ground-water supplies (Leenhouts and others, 2006). Significant amounts of unsaturated storage change can occur through transpiration processes where vegetation can access soil moisture within the root zone. Unsaturated-zone storage change occurs with infiltration of excess precipitation that is beyond vegetative-transpiration demands. Direct infiltration of precipitation rarely exceeds the root-zone soil-moisture deficit, resulting in little variation in storage below the root zone. Total soil-moisture variation in the upper $40 \mathrm{in}$. of the root zone typically is less than $1 \mathrm{in}$., but, on the basis of monitoring near Tombstone, Ariz., it can briefly increase to 3 in. following intense summer precipitation before returning to pre-existing conditions during a period of 1-2 months (written commun., Garry Schaefer, hydrologist, United States Department of Agriculture, Agricultural research Service). Extreme precipitation near Tombstone, from July 2000 to January 2001, about $20 \mathrm{in}$., resulted in as much as 7 in. of increased storage in the upper $40 \mathrm{in}$. of soil and helped maintain soil-moisture conditions at more than $1 \mathrm{in}$. above average through May 2001. Infiltration often exceeds transpiration demands where runoff is concentrated in ephemeral channels, resulting in deep percolation of infiltrated water and changes in water storage between the water table and the root zone. Unsaturated-zone changes in water storage can be large, as much as several feet, because depths to water typically are 50-300 ft or more. Data suggest that variations in the amount of water stored in the unsaturated zone can be an important component of nonaquifer storage change beneath ephemeral channels and in the root zone for a period of about 2 months following summer precipitation and for 4 months following periods of extreme winter precipitation. Much of the water that infiltrates the unsaturated zone beneath ephemeral channels likely recharges the water table and can be considered water that is available for withdrawal from the aquifer system.

Ground-water level declines have resulted in aquifersystem compaction and subsidence of the land surface in parts of Tucson Basin and Avra Valley (Hanson and Benedict, 1994; Hanson, and others, 1990). Strange (1983) analyzed repeated spirit-level surveys and documented less than $0.5 \mathrm{ft}$ of land subsidence near the center of Tucson Basin from 1952 to 1980 in an area where water levels declined as much as $160 \mathrm{ft}$ from 1940 to 1981 (Anderson, 1989a), and as much as $2.1 \mathrm{ft}$ of subsidence east of Picacho Peak in Avra Valley from 1948 to 1980, in an area where water levels declined as much as 140 ft from 1940 to 1985 (Anderson, 1989b), Rates of subsidence from 1976 to 1980 were $0.6-0.8$ in./yr near the center of Tucson Basin based on spirit-level surveys conducted by the National Geodetic Survey (Anderson, 1989a). Interferometric Synthetic Aperture Radar (INSAR) methods indicate a maxi- mum subsidence rate of about $0.4 \mathrm{in} . / \mathrm{yr}$ from 1993 to 2000 in the central part of Tucson Basin and undetectable subsidence in Avra Valley (Buckley, 2002).

\section{Methods}

Annual variations in ground-water storage and landsurface altitude in the TAMA were measured at networks of stations in Tucson Basin and Avra Valley (fig. 1). Additional hydrologic information, including measurements of water levels in wells, precipitation, streamflow, ground-water withdrawals, and artificial recharge, were correlated with measuredstorage and altitude change. Land subsidence was measured by using static differential GPS surveys. Storage change was measured by using gravity methods (Pool and Eychaner, 1995; Pool and Schmidt, 1997). Combined use of gravity and GPS methods were used to resolve components of ground-water storage change. Differential GPS data was used to resolve the portion of storage change that occurs due to expansion or contraction of saturated pore volume, and the gravity data are used to resolve the total storage change. The difference of storage change from the two methods is the storage change due to drainage or filling of pore spaces. Specific yield was estimated at stations located at monitor wells where water levels also were measured. Complete ground-water budgets were estimated for the periods between annual surveys.

Accurate repeat monitoring of ground-water storage and land subsidence requires vertically and horizontally stable monuments that are not susceptible to movement due to soil shrink and swell. Thus, suitable network stations require a concrete pad or monument that is well anchored to stable soil at depth. Many existing vertical and horizontal control monuments met the stability criteria and were chosen as stations. Other stations were constructed by using 2-inch brass caps placed in building foundations, concrete well pads, or crystalline rock.

\section{Differential Global Positioning System}

Vertical position of stations was monitored by using annual GPS surveys to determine any changes in altitude. Survey instruments were Trimble 4800 GPS receivers. Receivers were placed on fixed-height tripods at most stations to minimize errors in antenna-height measurements (fig. 3C). Surveys of Tucson Basin and Avra Valley networks were made by using multiple overlapping subnetworks of three to six stations. A single base station was common to every subnetwork. Stations were occupied for a minimum of $1 \mathrm{hr}$, and many stations were occupied for 1-8 hrs. More than 20 percent of the stations were reoccupied for redundancy and quality assurance. A least-squares network adjustment was applied to each of the annual surveys to establish station positions and overall survey accuracy. Adjustments of each annual survey were constrained by using horizontal and vertical positions that were held fixed at several stations. 


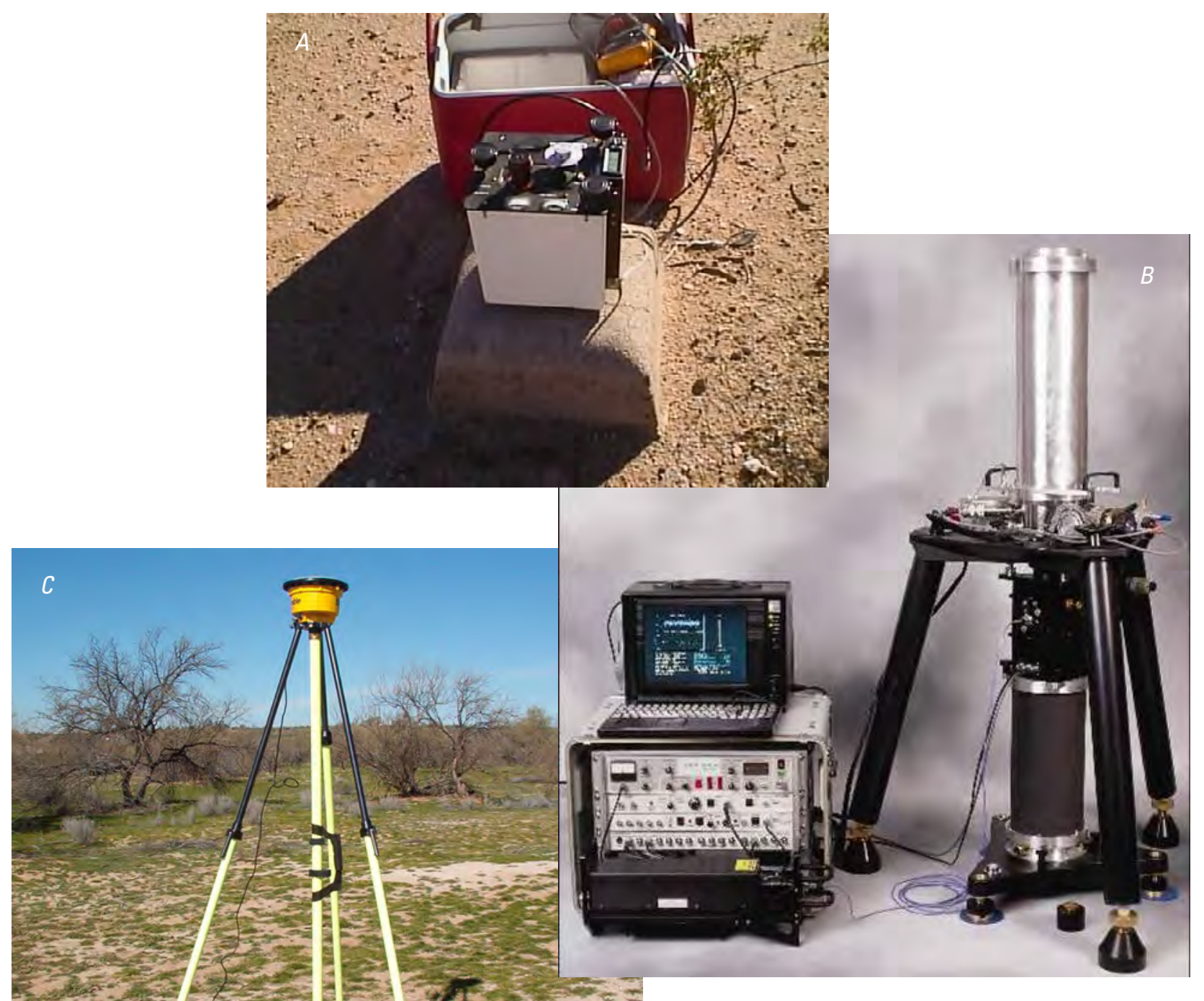

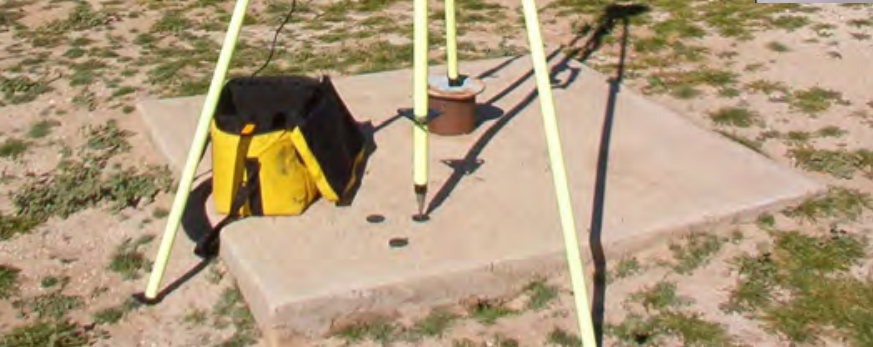

\section{Gravity}

Gravity methods are based on the principles of Newton's Law of Gravitation (Telford and others, 1990), which states that the acceleration of gravity within an object's gravitational field is directly related to the mass of the object and inversely related to the square of the distance to the center of the object. Thus, the greater an object's mass, the stronger the gravitational field. The object that produces the gravitational field in this case is the Earth, including ground water stored in aquifer systems and in the unsaturated zone between the land surface and the water table. Changes in the Earth's gravitational field at any location on the surface can be caused by changes in the
Figure 3. Photographs of gravity monitoring and Global Positioning System equipment. $A$, LaCoste Romberg Model $D$ relative gravity meter; $B$, Micro-g LaCoste FG-5 absolute gravity meter; $C$, Trimble 4800 differential global positioning system receiver.

amount of ground water in storage. Other subsurface mass change also can result in gravity change at the surface of the Earth, such as movement of mass in magma and geothermal reservoirs. Changes in ground-water storage, however, are the only likely cause of subsurface-mass change in the TAMA during the time scale of this study.

Gravity measurements were made by using relative and absolute meters (figs. $3 A-B$ ). Most gravity-data collection was done by using relative-gravity meters, which measure the difference in gravitational acceleration between stations. The absolute acceleration of gravity is established by measuring the value at selected stations by using an absolute-gravity meter. The absolute acceleration of gravity at other stations 
is then determined on the basis of the difference in gravity measured by using relative-gravity meters. Measurements of the relative difference in gravity among stations were made by using Lacoste and Romberg Model D gravity meters (fig. 3A). Observations of absolute gravity were made by the NGS using an FG-5 falling-mass gravity meter manufactured by Micro-g LaCoste, Inc. of Lafayette, Colo. (fig. 3B).

The absolute acceleration of gravity was monitored at 5 stations (fig. 1). Annual observations at each station included hourly sets of several hundred individual measurements made during a period of 24 hours or more. Data are corrected for theoretical Earth tides, location of the rotational axis of the Earth, and barometric pressure $(-0.35 \mu \mathrm{Gal}$ per millibar). Resulting values of gravitational acceleration are the average of the hourly measurements reduced to the height from which the falling mass is released (drop height) at $131 \mathrm{~cm}$ above a station monument. Observations under ideal conditions generally are accurate to within about $\pm 2 \mu \mathrm{Gal}$, which is equivalent to the change in gravity resulting from the addition or removal of an extensive layer of water that is about 2 in. thick. Accuracy may be degraded by ground motion caused by local construction activity, seismic activity, atmospheric disturbances, and large variations in temperature. Temperature variations were minimized by locating stations in buildings where the temperature is controlled or varies minimally.

The inclusion of absolute-gravity observations in both aquifer and nonaquifer areas provided quality control for observation of gravity change from the relative-gravity surveys and for the possibility of observing gravity variations that are caused by mass change outside of the aquifer. Two stationsTUCSON AC and TUCSON AD-were located on alluvium and within the extent of the regional aquifer system. Three stations-TUCSON AA, TUCSON AE, and TUCSON $\mathrm{AF}$ - were located on rocks of low porosity that lie outside the aquifer-system extent where gravity variations caused by ground-water storage changes are likely to be smaller than the accuracy of the measurement. The detection of significant variations in gravity at stations located on low porosity rocks may be caused by a more extensive regional aquifer system than expected or other storage-related changes, such as altitude change or nearby soil-moisture variations. Simple gravity models, constrained by nearby water-level variations and extent of the aquifer system, can be used to establish the likely causes of significant variations in gravity in areas of low-porosity rock.

Annual relative-gravity surveys of two regional networks of stations in Tucson Basin and Avra Valley were completed by using several sub-surveys of 5-10 stations to establish gravity differences among stations. Inclusion of stations where the absolute acceleration of gravity also was measured allowed for the calculation of absolute gravity at each station in the network. Specific meters were dedicated to relative-gravity surveys of the two regional networks to maintain consistency in meter calibration throughout all surveys. Meter D-127 was used in Tucson Basin, and meter D-209 was used in Avra Valley. Surveys were reduced to gravity differences between stations by converting meter readings to gravity units and correcting for estimated Earth-Tides (Longman, 1959) and linear-meter drift. Each subsurvey included a minimum of two measurements at each station and a minimum of three measurements at a designated reference station. Multiple repeats of stations allowed for monitoring of survey drift. Additional measurements were made in subsurveys where survey drift was found to be non-linear. Subsurveys sometimes were repeated due to excessive nonlinear survey drift. Final surveys generally resulted in a standard deviation of $6 \mu \mathrm{Gal}$ or less in the gravity difference among stations in the subsurvey, however, the standard deviations of differences among stations often were much less. Network redundancy and quality control was accomplished with inclusion of a reference station in a subsurvey that was in common with another subsurvey. All reference stations in Tucson Basin also were tied directly to observations of absolute gravity at a minimum of 2 of the 3 absolute-gravity stations in the basin-TUCSON AA, TUCSON AD, and TUCSON AE. All stations in Avra Valley were tied to observations of absolute gravity at station TUCSON AF.

Estimates of ground-water storage change were made for periods between surveys for Tucson Basin and Avra Valley networks by using the excess-mass method (Telford and others, 1976). The excess-mass method sums the gravity or storage change across the monitored area. Two important assumptions apply to the use of the excess-mass method for these data sets, (1) the distribution of gravity change is adequately sampled and (2) gravity change outside of the monitored region that is caused by mass change within the region is small. Accurate estimates of storage change require that the spacing between stations be sufficiently small that gravity change among stations is spatially correlated. Variations in gravity change that occur at distances less than the station spacing result in under sampling of the gravity change and greater uncertainty in resulting estimates of storage change. Unmeasured gravity change that is outside of the monitored area and caused by ground-water storage change within the monitored area results in underestimation of total storage change. The magnitude of this error is small where the area of unmonitored gravity change is small in comparison to the area of the monitored region. Estimation of the unmonitoredgravity change area requires estimation of the maximum distance that gravity change may be detected beyond the monitored region, which can be made on the basis of the maximum depth to the storage change-about $500 \mathrm{ft}$ in the study area. The gravity change caused by $1 \mathrm{ft}$ of water at a depth of 500 $\mathrm{ft}$ throughout the monitored region would be undetectable at a distance of about 1,000 ft from the edge of the mass change (the edge of the aquifer). The area within 1,000 ft of the monitored regions represent about 8 percent of the monitored area for Tucson Basin and about 6 percent of the monitored area for Avra Valley. The average gravity change within 1,000 ft of the aquifer is about one-half of the change measured at the edge of the monitored area on the basis of a theoretical semi-infinite horizontal slab approximation for the aquifer-storage change (Telford and others, 1976). Accordingly, the total storage- 
change error contributed by the unmonitored region is about 4 percent for the Tucson Basin network and 3 percent for the Avra Valley network.

\section{Water Levels in Wells}

Water levels in wells were measured on an annual or more frequent basis as an approximation of variations in the water table and unconfined aquifer storage at wells near storage-monitoring stations and at many additional wells in the study area. Variations in water levels are a measure of variations in hydraulic head of the relatively more permeable aquifers penetrated by the well screen, which is the portion of the well casing that is designed to allow water to flow between the aquifer and the well bore. Variations in hydraulic head in the aquifer are indicators of variations in water stored in the monitored aquifer system. Increases in hydraulic head generally indicate an increase in storage, and decreases in hydraulic head generally indicate a decrease in storage in the monitored aquifer. The amount of the change in storage with water-level change requires information about the aquifer storage coefficient, or storativity, a property that describes the ability of the aquifer to store water, and is defined as the volume of water that can be released from storage within a unit surface area of aquifer per unit change in hydraulic head (Freeze and Cherry, 1979). Unconfined aquifers yield more water from storage per unit decline in head than confined aquifers because a decline in the water table results in the drainage of water from pore spaces within the zone of water-table decline. The storage coefficient for unconfined aquifers is generally greater than 0.01 and is known as specific yield (Sy). Sy values vary greatly with grain size. Little water drains from the pores between silt and clay grains resulting in low Sy. Sand and gravel intervals generally have the highest values of Sy. The high degree of heterogeneity of intervals of silt and clay and intervals of sand and gravel interbedded within the aquifers indicate that values of Sy should vary greatly throughout the aquifers in the aquifer system. Estimates of an average value of Sy for a heterogeneous alluvial aquifer, such as in the aquifer system in the study area, are therefore, uncertain.

The multiple aquifers within the aquifer system in the study area are moderately-well to well-connected hydraulically, and water levels in wells that tap the aquifers generally are considered to represent the water table. However, significant aquitards occur in parts of the study area resulting in local aquifers and perched aquifers that are not hydraulically well connected. Depending on the well construction, variations in water levels in wells in these areas may not be representative of variations in the water table and unconfined aquifer storage (fig. 4). Several typical well-construction and water-level scenarios are shown in figure 4 for two common hydrogeologic conditions that occur in the study area, (1) a poorly connected regional aquifer system with upward flow of ground water across an aquitard from a deep confined aquifer to a shallow unconfined aquifer, and (2) a perched aquifer that drains to a regional unconfined aquifer, Three well-construction scenarios are common within each hydrogeologic condition, (1) a shallow well that is screened in the shallow unconfined or perched aquifer (well-construction scenarios $A$ and $E$ ), (2) a deep well that is screened within both the shallow and deep aquifers (well-construction scenarios $B$ and $F$ ), and (3) a deep well that is screened in only the deep aquifer (well-construction scenarios $C$ and $D$ ). Within each hydrogeologic condition, water-level changes in a single well are insufficient to describe the direction of storage change within the deep and shallow aquifers. Water-level variations under well-construction scenario $A$ are representative of water-table variations in the regional unconfined aquifer. Water-level variations under wellconstruction scenario $B$ are representative of variations in the composite hydraulic head in the shallow and deep aquifers and may not represent variations in the water table. Water-level variations under well-construction scenario $C$ are representative of variations in a hydraulic head in the deep confined aquifer and do not represent variations in the water table. Water-level variations under well-construction scenario $D$ are representative of water-table variations in the regional unconfined aquifer. Water-level variations under well-construction scenario $E$ are representative of water-table variations in the unconfined perched aquifer. Water-level variations under wellconstruction scenario $F$ represent variations in the rate of flow of cascading water through the well from the perched aquifer to the deep regional unconfined aquifer and variations in the water table in the deep unconfined aquifer. These multiple scenarios suggest that the complex nature of the aquifer system and variations in well construction result in water-level variations that may not be good indicators of variations in storage in the regional aquifer system.

\section{Specific Yield}

Estimates of Sy were made where ground-water storage monitoring stations were located at water-level monitoring wells. Gravity change was converted to storage change by assuming the interval of ground-water storage change at the well can be approximated by using the theoretical infiniteslab relation of $12.77 \mu \mathrm{Gal} / \mathrm{ft}$ of water. Linear correlations of change in storage and water-level altitude were determined at each station. Sy was estimated as the slope of the linear correlation.

\section{Ground-Water Budget}

Ground-water budgets during the period between annual surveys were estimated for the monitored regions of Tucson Basin and Avra Valley by using water-balance methods (Equation 1):

$$
\Delta S=G W_{\text {in }}-G W_{\text {out }}
$$

Storage change $(\Delta S)$ was estimated by using the excess mass-change equation (Telford and others, 1976). Outflow 


\section{Selected well construction scenarios in a multiple aquifer system}

A. Well screened in shallow unconfined aquifer with lower hydraulic head than in the deep confined aquifer. Water level in the well represents hydraulic head in the shallow aquifer and approximates regional aquifer water table.

B. Well screened in shallow unconfined aquifer and deep confined aquifer with higher hydraulic head than in the shallow aquifer. Upward flow occurs in borehole. Water level in the well represents a hydraulic head that is a composite of the two aquifers and does not approximate the shallow aquifer water table.

C. Well screened in deep confined aquifer with higher hydraulic head than shallow unconfined aquifer. Water level in the well represents hydraulic head in deep confined aquifer and does not approximate water table.

D. Well screened in regional unconfined aquifer. Water level in the well represents hydraulic head in the regional aquifer and approximates regional aquifer water table.

E. Well screened in perched unconfined aquifer. Water level in the well represents hydraulic head in the perched aquifer and approximates perched aquifer water table.

F. Well screened in perched and regional aquifers with water cascading into well from the perched aquifer through screened intervals. Water level in the well represents hydraulic head that is greater than the hydraulic head in the regional aquifer and does not approximate the regional or perched aquifer water table.

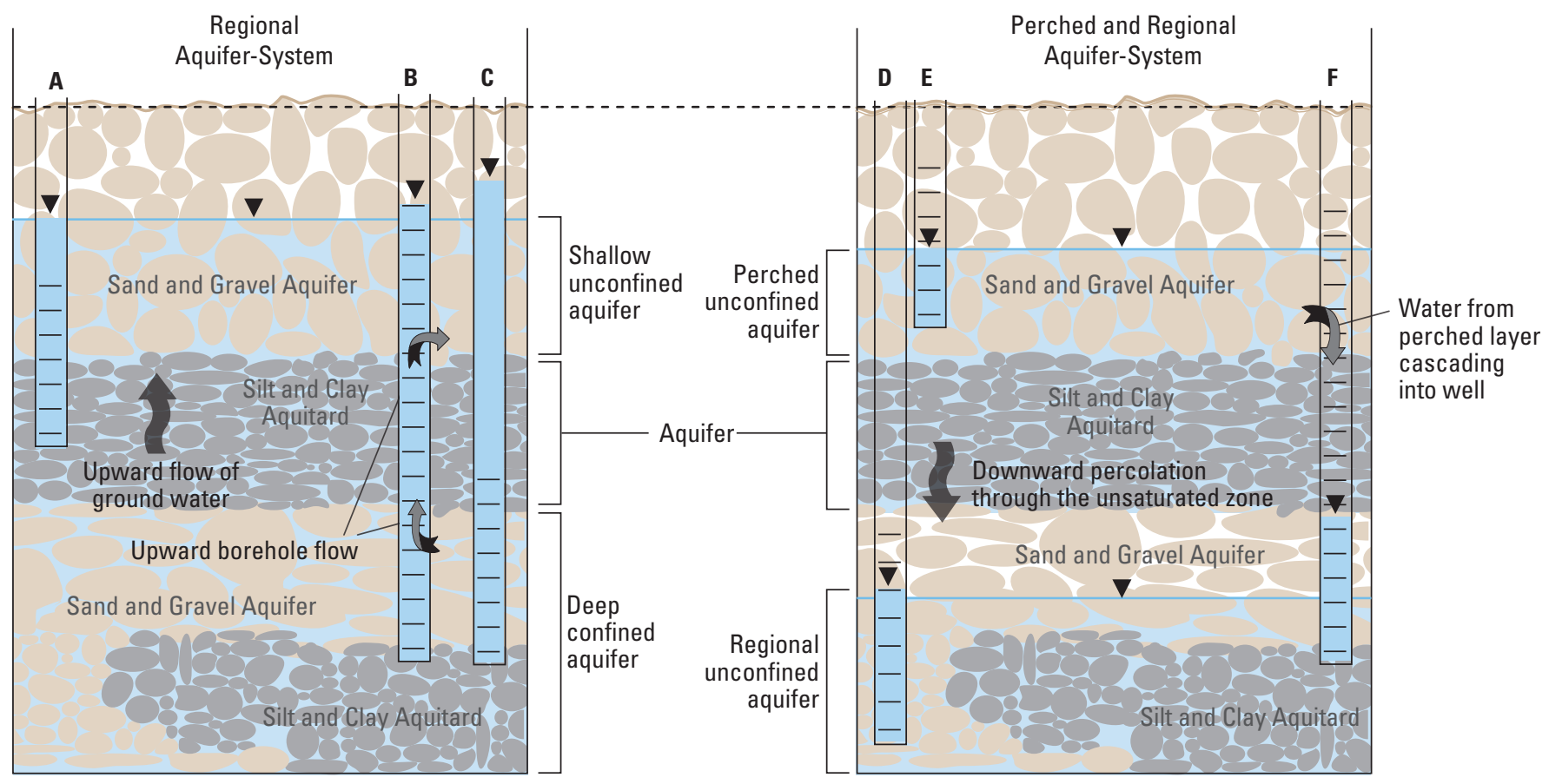

Figure 4. Selected representations of common relations between hydraulic head, screened intervals, water levels in wells, and water tables in the Tucson Active Management Area.

from the ground-water system $\left(G W_{\text {out }}\right)$ was estimated as the sum of estimated evapotranspiration, ground-water outflow, and ground-water withdrawals. Ground-water withdrawals are reported for large-production wells and estimated for small wells (wells with a pump capacity of less than $35 \mathrm{gpm})$. Ground-water inflow $\left(G W_{\text {in }}\right)$ includes the sum of natural and artificial recharge within the monitored regions and ground-water inflow across the boundaries of the regions. $G W_{\text {in }}$ was estimated as a residual of estimated ground-water outflow $\left(G W_{\text {out }}\right)$ and storage change $(\Delta S)$. Natural inflow to the ground-water system, which includes natural recharge and ground-water inflow, was estimated as the difference of total ground-water inflow $\left(G W_{\text {in }}\right)$ and reported artificial recharge. Assumptions of the estimated ground-water budgets include the assumption that ground-water flow across boundaries is constant during the monitoring period and unsaturated-zone storage near stations does not vary among measurements.
Variations in flow across boundaries probably are minimal because hydraulic gradients near boundaries probably vary less than 1 percent. Unsaturated-zone storage could potentially vary within the root zone and result in a gravity variation of a few $\mu \mathrm{Gal}$ between measurements. Soil-moisture variation among surveys was minimized by locating stations in areas of local topographic highs and completing surveys during the same season each year.

\section{Precipitation and Streamflow}

Changes in ground-water storage are influenced by rates and seasonality of precipitation that result in infiltration of streamflow, deep percolation through the unsaturated zone, and recharge. Precipitation records at stations in Tucson Basin and Avra Valley-University of Arizona Campbell Road 


\section{A. PRECIPITATION}

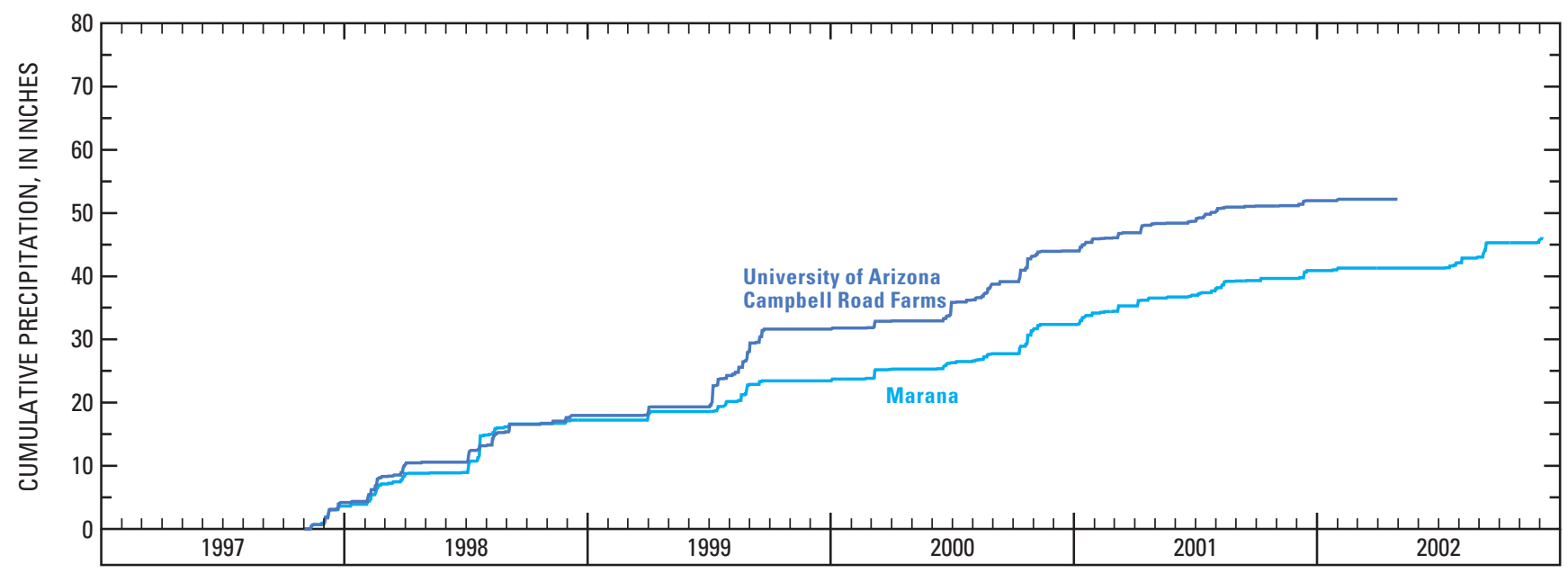

B. STREAMFLOW

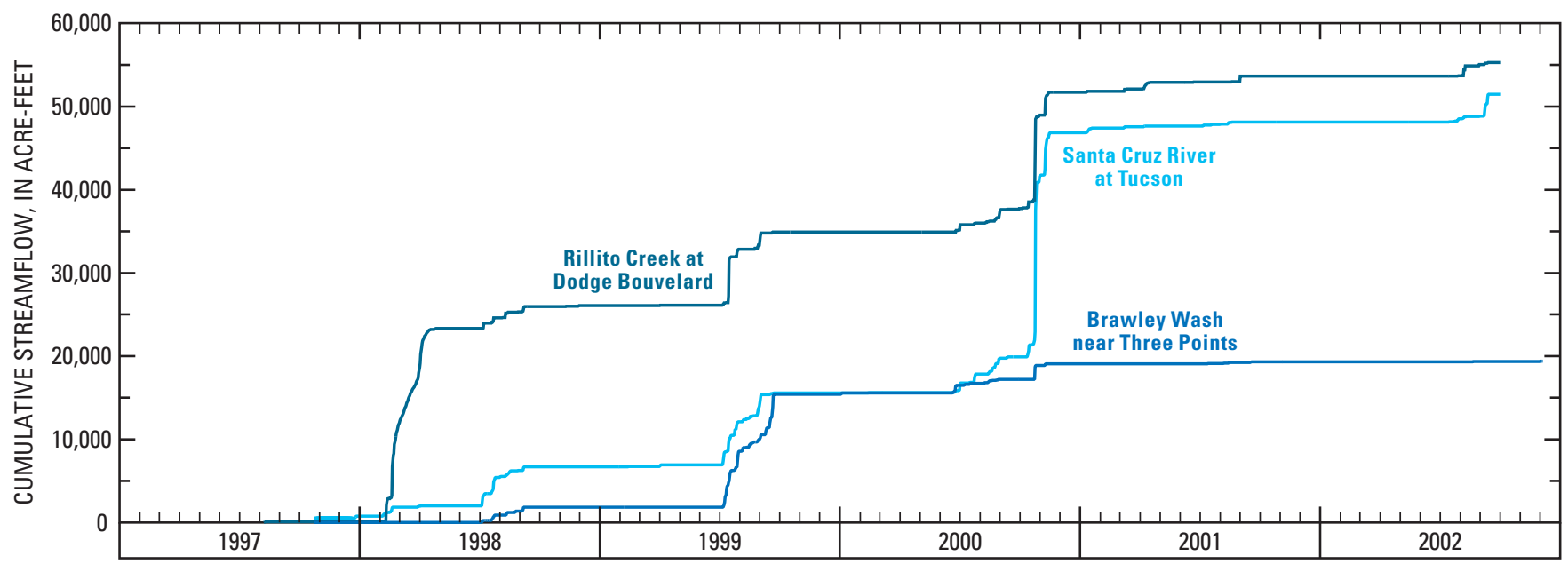

Figure 5. Precipitation and streamflow at selected stations within the Tucson Active Management Area, 1997-2002. A, Precipitation at University of Arizona Campbell Road Farms and Marana; B, Streamflow on the Santa Cruz River at Tucson, Rillito Creek at Dodge Boulevard, and Brawley Wash near Three Points.

Farms and Marana, respectively_-show significant variability during the monitoring period (fig. $5 A$ ). Most precipitation from the monitoring period at both stations occurred during three periods, including winter 1998, summer 1999, and fall 2000. Precipitation during any season was similar at both stations with the exception of the summer 1999 when more than 11 in. occurred at Tucson North, and about 4 in. occurred at Marana. Periods of little precipitation occurred at both stations during fall 1998 through winter 1999, fall 1999 through winter 2000, and winter 2000 through winter 2001.

Variations in streamflow on the major ephemeral streams of the area, Santa Cruz River, Rillito Creek, and Brawley Wash, are indicators of precipitation that was available for infiltration and natural recharge to the aquifer (fig. $5 B$ ). Differences in the periods of major streamflow at each station indicate that recharge was spatially and temporally variable across the TAMA. The greatest rates of streamflow for each stream occurred during winter 1998 on Rillito Creek, during summer 1999 on Brawley Wash, and during fall 2000 on Santa Cruz River. Significant streamflow also occurred during summer 1999 on the Santa Cruz River and Rillito Creek. The temporal distribution of streamflow indicates that the greatest rates of recharge in Tucson Basin likely occurred in the northern part of the basin during the winter and summer of 1998 and in the southern part of the basin during fall 2000. The greatest rates of recharge in the southern Avra Valley likely occurred during summer 1999. The Santa Cruz River, Rillito Creek and Brawley Wash coalesce near northern Avra Valley, resulting in temporal distributions of recharge that were likely strongly influenced by infiltration of streamflow contributions from each of the major streams during the winter and summer of 1998, summer 1999, and fall 2000. Deviations 
of the streamflow trends from precipitation trends at Tucson North and Marana suggest that the two precipitation gages are insufficient for estimating the distribution of precipitation in the TAMA.

\section{Water-Level Change}

Water-level trends in the TAMA during the period of investigation generally reflect the trend in ground-water withdrawals, precipitation, streamflow, and natural and artificial recharge. Trends are displayed by using hydrographs of water levels in wells at and near storage-monitoring stations in Tucson Basin (fig. 6A) and Avra Valley (fig. 6B) and by using maps of water-level change at wells (Elizabeth Green, hydrologist, Tucson Water, written commun., November, 2002) for winter 1998 to winter 1999 (fig. 7A) and winter 1999 to winter 2002 (fig. 7B) periods. The dominant trend generally was declining water levels in response to general overdraft conditions, except at wells that are near sources of natural and artificial recharge which display brief or sustained water-level recovery. The greatest change in water levels occurred near major ephemeral streams following the wet winter of 1998, which resulted in a general water-level recovery from winter 1998 to winter 1999 followed by generally declining water levels.

\section{Tucson Basin}

The general trend of water levels in Tucson Basin during the monitoring period included water-level recovery near major streams following winter 1998 and decline from 1999 to 2002 in response to regional ground-water withdrawals and redistribution of the recently recharged water (fig. 7A). Local water-level recovery or reduced rates of water-level decline from 1999 to 2002 followed other local recharge events near Rillito Creek and the Santa Cruz River and near artificial recharge facilities. Water levels in wells that are not near the major streams gradually declined or changed little during the monitoring period.

Water levels near Rillito Creek and the Santa Cruz River generally recovered 10-20 ft from winter 1998 to winter 1999 and declined less than $10 \mathrm{ft}$ throughout most of the remainder of the basin (fig. 7A). From 1999 to 2002, water levels declined less than $10 \mathrm{ft}$ across much of the basin (fig. $7 B$ ). The greatest water-level decline of 10-30 ft from 1999 to 2002 occurred near Rillito Creek as water levels that were temporarily high following winter 1998 dissipated as the recently recharged water was redistributed throughout a larger area of the aquifer system. Peak water-level recovery at some wells, including A-54A and B-77A (fig. 6A), occurred a year or longer after winter 1998 streamflow. Water levels responded more quickly to ephemeral-channel recharge at some wells, including at well SS-016A-near storage monitoring station N419 (fig. 6A) —where the measured water level declined about $15 \mathrm{ft}$ during winter 1998-fall 2000. Any water-level recovery at the well was not captured by the infrequent water-level measurements at the well. Rapid water-level response to recharge at well SS-016A was observed with a slight water-level recovery of $3 \mathrm{ft}$ following recharge during winter 2001.

Water levels from 1999 to 2002 were dominated by recovery in two areas-near the Santa Cruz River south of Tucson and near the confluence of the Santa Cruz River, Rillito Creek, and Cañada del Oro (fig. 7B). Near the Santa Cruz River, water levels continued to recover following October 2000 streamflow, but the greatest recovery of more than $10 \mathrm{ft}$ occurred near an artificial-recharge facility in the southern part of the basin (fig. 7B). Water-level recovery of 10-30 ft that occurred near the confluence of the Santa Cruz River, Rillito Creek, and Cañada del Oro likely resulted from continued recovery following recharge during winter 1998.

Short-term water-level variations at several wells likely are related to recharge along streams that are tributary to the Santa Cruz River and Rillito Creek. Water-level recovery during winter 1998 at well B92A (fig. 6A) was likely related to infiltration and recharge along nearby Pima Wash. Waterlevel rises of more than $20 \mathrm{ft}$ from winter 1998 to winter 1999 at well A-055A-near storage-monitoring station TUCSON AA (fig. 6A)-indicates increased aquifer storage that likely resulted from infiltration and recharge along nearby Sabino Creek. Well WR-055A also displays water-level recovery of about $10 \mathrm{ft}$ following streamflow during October 2000. Waterlevel decline of several feet from winter 1998 to winter 1999 at wells WR-147A and WR-118A-near storage-monitoring stations MAGNETIC and TUCSON AC (fig. 6A), respectivelyprobably represents return to pre-1998 levels following winter 1998 infiltration and recharge along nearby Pantano Wash and Tanque Verde Creek.

Trends of water-level recovery occurred throughout the monitoring period at several wells located near artificialrecharge facilities. Water levels recovered $10 \mathrm{ft}$ or more at wells SC-017A and SC-005A-near storage-monitoring stations XAVIER and L75 (fig. 6A), respectively—which are near the Pima Mine Road recharge facility that began operations in 1998.

\section{Avra Valley}

Water levels in northern and central Avra Valley generally increased throughout the monitoring period as a result of infiltration and recharge of natural streamflow along the Santa Cruz River and infiltration of effluent and imported surface water at artificial-recharge facilities.

Water levels near the Santa Cruz River recovered as much as $30 \mathrm{ft}$ during the monitored period, including as much as 10 $\mathrm{ft}$ of recovery that occurred from winter 1998 to winter 1999 (fig. 7A) and an additional 20-30 ft that occurred from winter 1999 to winter 2002 (fig. 7B). Water-level recovery at these wells likely was enhanced by recharge of natural streamflows and effluent flows along the Santa Cruz River and probable low storage coefficients in a part of the aquifer that includes a large 
A. Tucson Basin
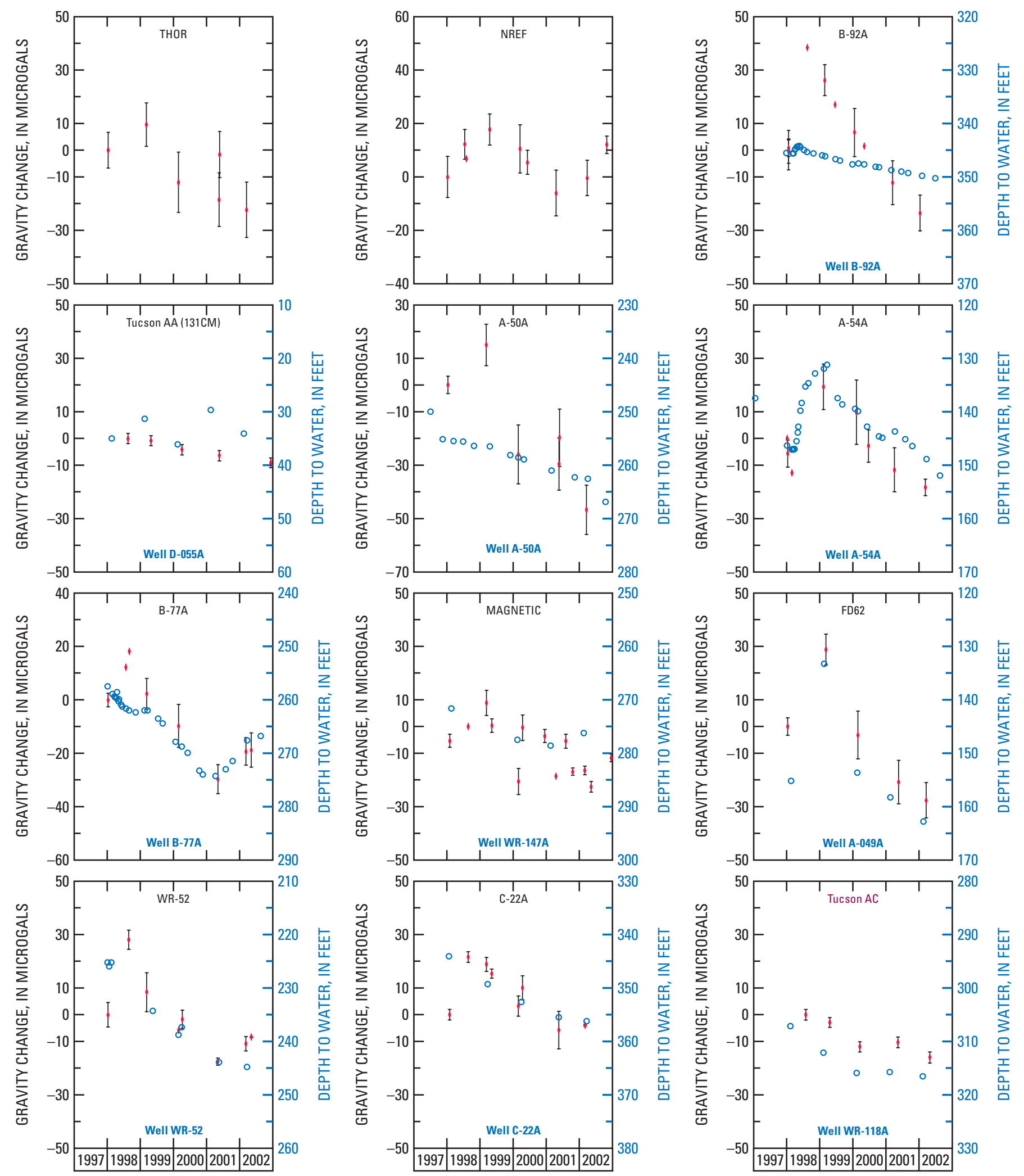

Figure 6. Gravity and water-level change at ground-water storage monitoring stations within the Tucson Active Management Area winter 1998 to spring 1002: A, Tucson Basin; B, Avra Valley. 
A. Tucson Basin
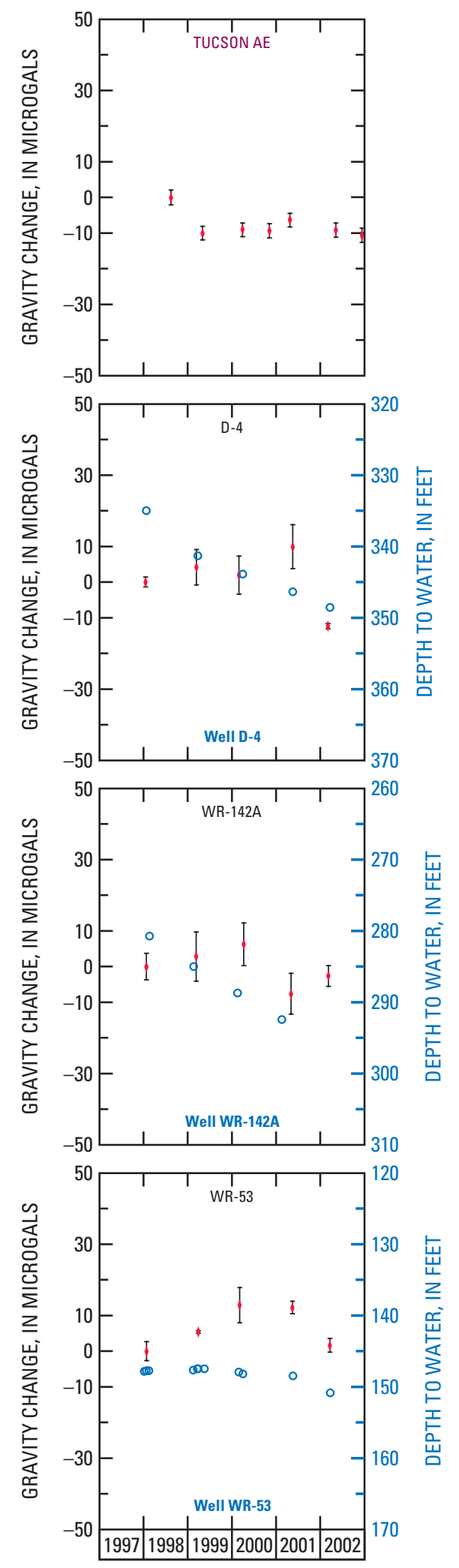
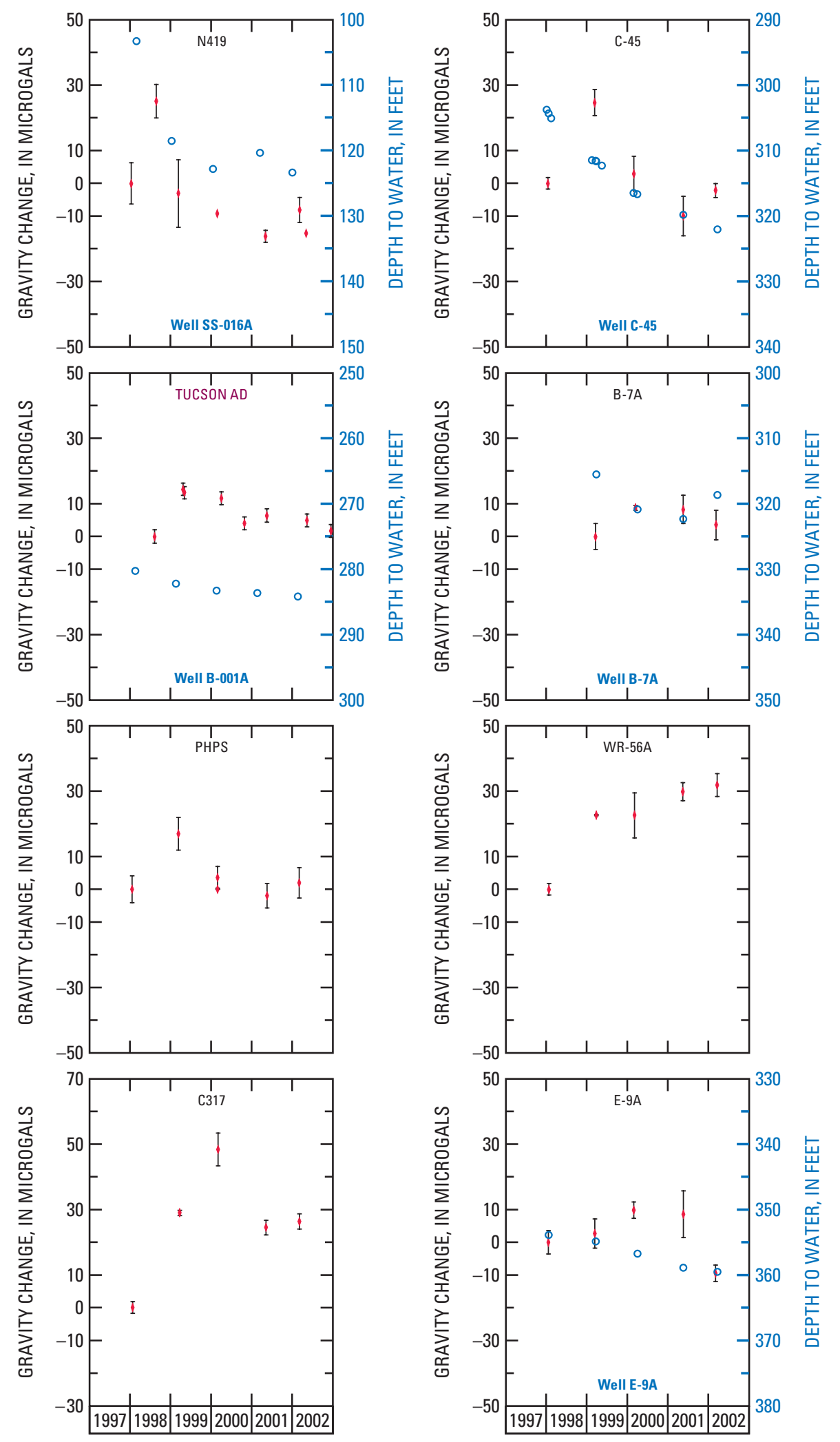

Figure 6. Gravity and water-level change at ground-water storage monitoring stations within the Tucson Active Management Area winter 1998 to spring 1002: A, Tucson Basin; B, Avra Valley-Continued. 
A. Tucson Basin
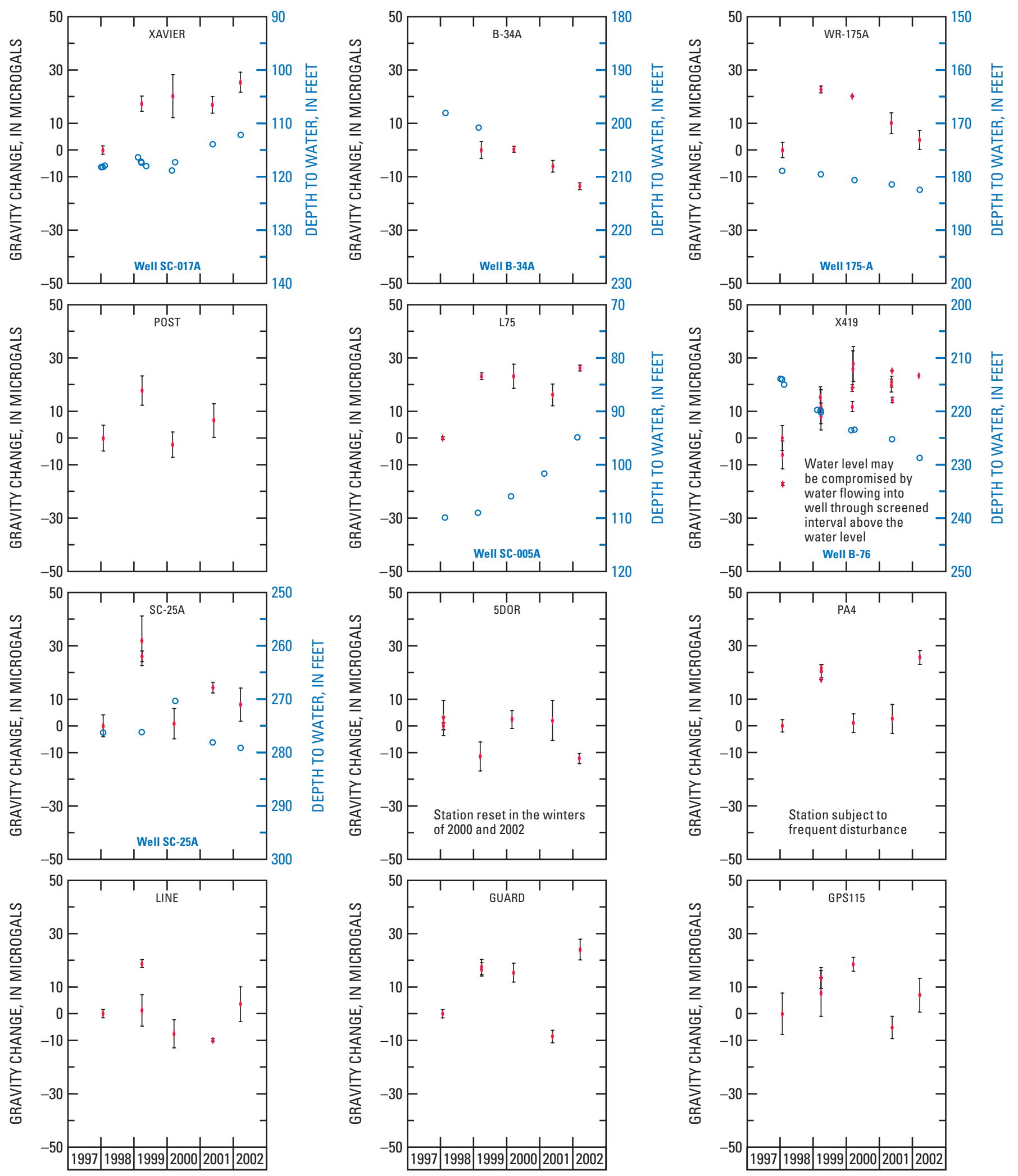

Figure 6. Gravity and water-level change at ground-water storage monitoring stations within the Tucson Active Management Area winter 1998 to spring 1002: A, Tucson Basin; B, Avra Valley-Continued. 


\section{B. Avra Valley}
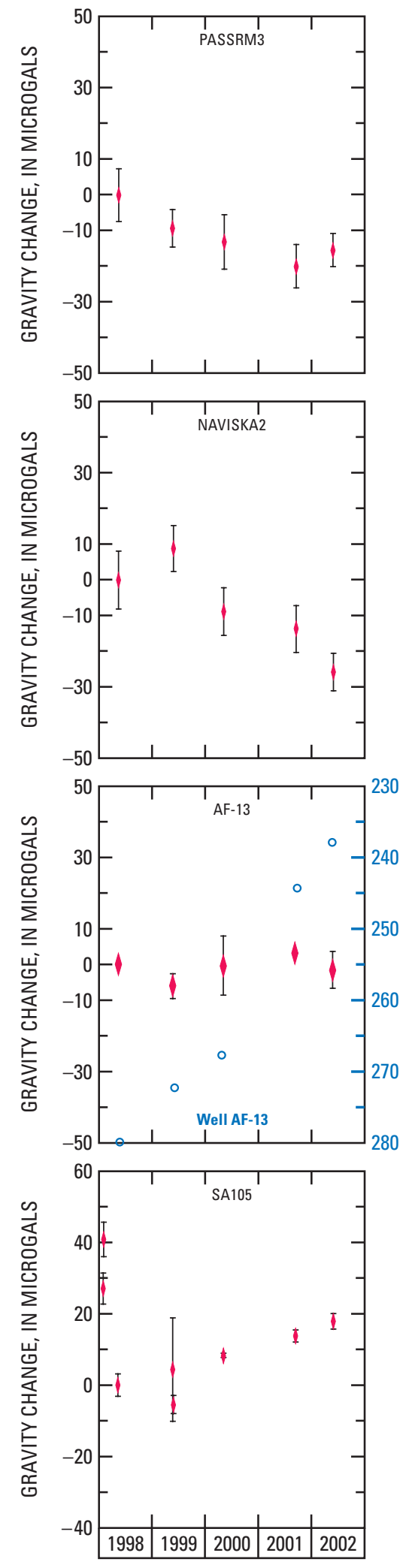
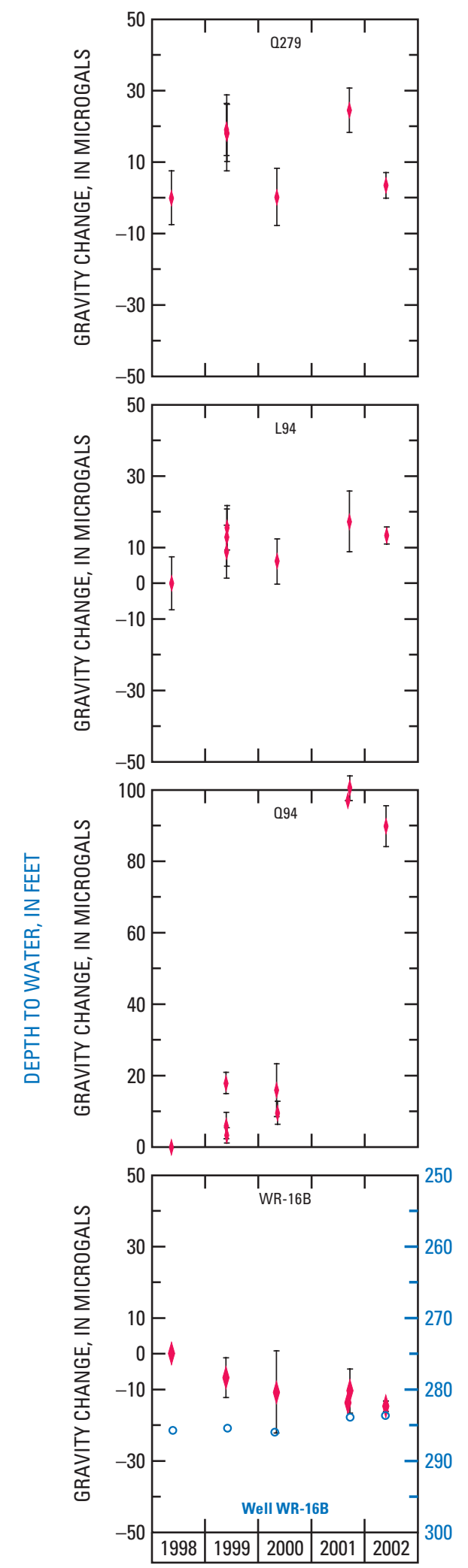
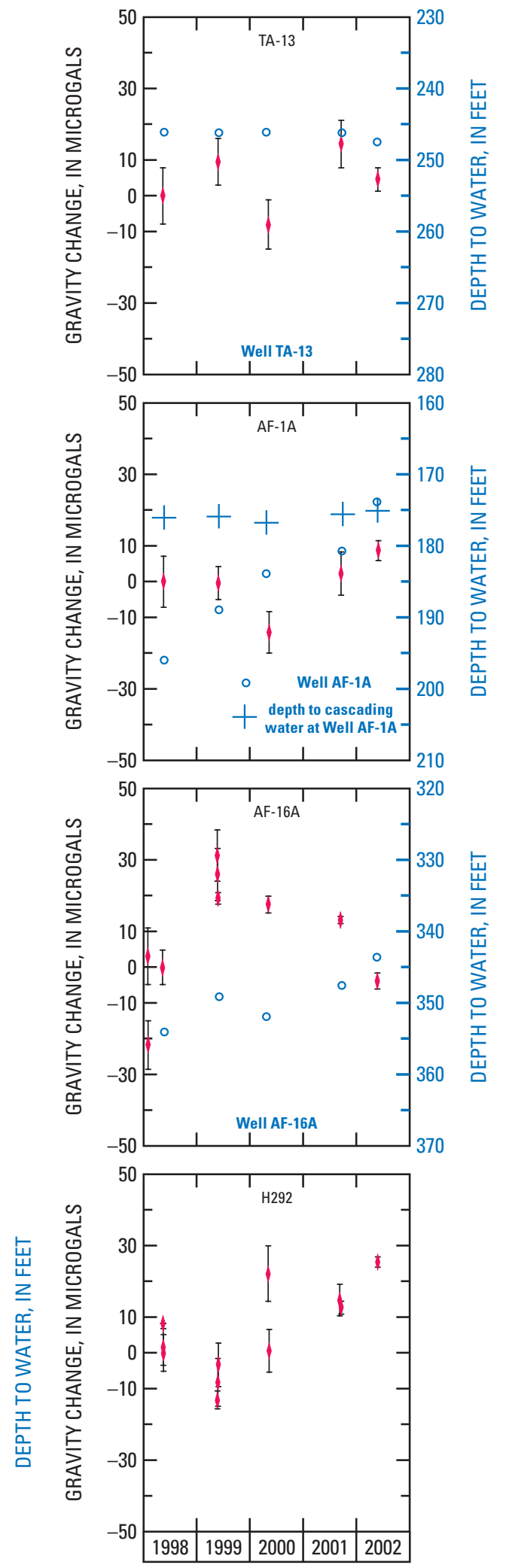

Figure 6. Gravity and water-level change at ground-water storage monitoring stations within the Tucson Active Management Area winter 1998 to spring 1002: A, Tucson Basin; B, Avra Valley-Continued. 
B. Avra Valley
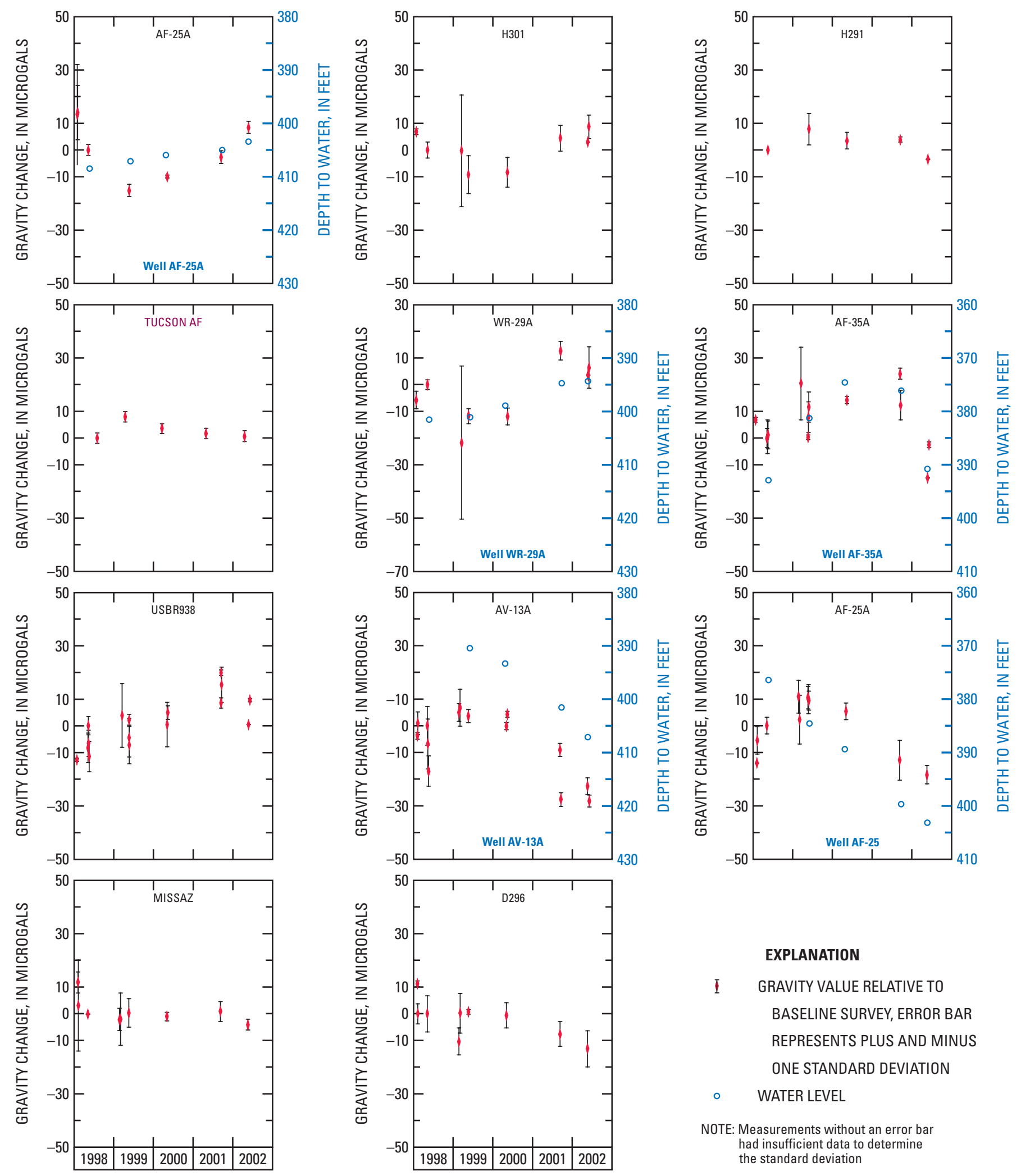

Figure 6. Gravity and water-level change at ground-water storage monitoring stations within the Tucson Active Management Area winter 1998 to spring 1002: A, Tucson Basin; B, Avra Valley-Continued. 
amount of silt and clay (Anderson, 1989b). Intervals of silt and clay in the region separate the regional aquifer system into deep confined, unconfined, and shallow perched aquifers, resulting in complex water-level response to changes in inflow and outflow. Water levels at well AF-1A are representative of wells in the region (fig. 6B). AF-1A is an abandoned agriculturalwithdrawal well that is screened across both a shallow perched aquifer and a deep aquifer, resulting in a water level that may not be representative of either aquifer. The perched aquifer may not have existed when the well was first drilled, but could have developed as agricultural withdrawals lowered the hydraulic head in the regional aquifer below the level of the local aquitard. During the study period, water flowed into the borehole through the portion of the screen that is open to the perched aquifer and cascaded through the borehole to the water level in the well. The water level in the well, therefore, likely represents a hydraulic head that is greater than the hydraulic head in deep aquifer. The water level in well AF-1A recovered more than $20 \mathrm{ft}$ from winter 1998 to winter 2002. By winter 2002, the water level in the well AF-1A had risen to near the level of water entering the well from the perched aquifer. Water-level changes in the well may not be representative of storage change in the perched or deep aquifer. Storage in the deep aquifer increased on the basis of the water-level recovery, but storage change in the shallow perched aquifer and overall storage change is unknown on the basis of water levels.

Water-levels in the central and southern parts of Avra

Valley generally declined during the monitoring period. Water levels declined less than $5 \mathrm{ft}$ during winter 1998- winter 2002 in the south-central part of Avra Valley in an area that includes a municipal well field (figs. $7 A$ and $7 B$ ). Water levels near the artificial-recharge facility in central Avra Valley recovered several feet at wells AF-35A, AF-25, and WR-29A (fig. 6B) after operations began in 1998. The aquifer system includes silt and clay aquitards in central Avra Valley, but few in the southern part of the area (Anderson, 1989b). As a result of few significant aquitards, water-level changes in central and southern Avra Valley are likely to represent the sense of overall changes in aquifer-system storage.

\section{Land Subsidence}

Land subsidence was monitored annually at stations in the Tucson Basin and Avra Valley networks (fig. 8) by using GPS technology. Each annual survey was completed during a period of about 2 weeks by using geodetic GPS receivers operated by Pima County and the USGS and a base station receiver (COT1) operated by the City of Tucson. The base station was also a Continuously Operated Reference Station (CORS), the data for which are stored by the NGS and are accessible through a website (http://www.ngs.noaa.gov/CORSh). Final station positions were determined through a least-squares adjustment of each network by using several control stations that are assumed to have stationary positions and are not adjusted. The control stations were on the margins of the networks on crystalline rock, near crystalline rock, or in areas where land subsidence was expected to be minimal. Stationary control points included 5 stations-TUC, N419, POST, GUARD, and THOR - in Tucson Basin and 2 stations-H291 and PASS - in Avra Valley (fig. 9A). Station positions that resulted from the least-squares adjustment were generally accurate to within $0.79 \mathrm{in}$. in the vertical position and $0.39 \mathrm{in}$. in the horizontal position. Results of the network adjustments of each annual survey were differenced to determine changes in station vertical position and land subsidence.

Horizontal coordinates and ellipsoid heights for each station were determined in the NAD83 coordinate system for GPS surveys done during summer 1998, spring 1999, spring 2000, spring 2001, and spring 2002 (table 1). Differences between the position results of the summer 1998 and later surveys suggest that a few important measurements made during the summer 1998 may have been biased and resulted in a regional trend in the adjusted positions. Changes since the spring 1999 survey likely are more reliable (fig. 8). Results indicate that land-subsidence of more than $1 \mathrm{in}$. during the monitoring period was measurable at a few stations in Tucson Basin and at only a single Avra Valley station located north of Marana (fig. 8). Subsidence of 1-3 in. occurred at 8 stations in the central Tucson Basin from spring 1999 to spring 2002. The stations occur within a region where land subsidence was documented from 1989 to 1998 by using GPS methods (Pool and others, 2000) and from 1993 to 2000 by using INSAR methods (Buckley, 2002). GPS derived rates of subsidence from 1998 to 2002 were similar to those measured during the earlier period.

\section{Gravity and Ground-Water Storage Change}

Annual gravity surveys of the ground-water storage monitoring networks generally were done during FebruaryApril in Tucson Basin and during May in Avra Valley. Baseline relative-gravity surveys were completed in December 1997 in Tucson Basin and May 1998 in Avra Valley. The Tucson Basin network was augmented with results of seasonal surveys of networks near Rillito Creek and the Lower Cañada del Oro subbasin from 1998 to 2002 and near the Santa Catalina Mountains (Foothills) from 1999 to 2002 (fig.1). Gravity control for the relative gravity station surveys was established with observations of absolute gravity at 5 stations (fig. 1) beginning in late-July 1998 and done, thereafter, from the spring of 1999 to 2002. Supplemental absolute-gravity observations also were made at 3 of the 5 absolute-gravity stations during fall 1999-2002. Annual monitoring of the complete network with both relative and absolute gravity surveys occurred from 1999 to 2002.

The absolute acceleration of gravity was calculated at each of the relative-gravity stations by summing the abso- 


\section{A. Winter 1998 to winter 1999}

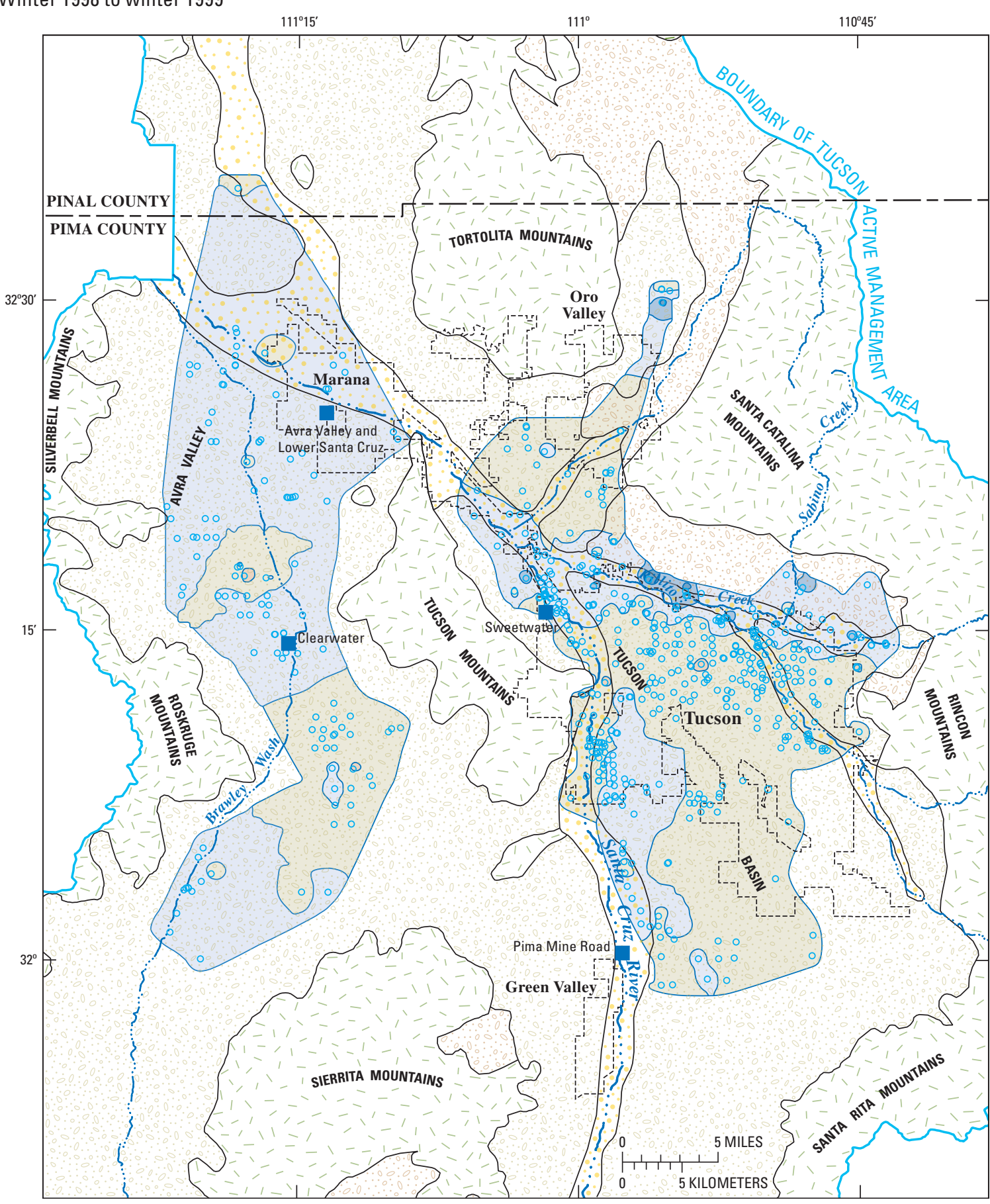

Base from U.S. Geological Survey

digital data, 1:100,000, 1982

Universal Transverse Mercator

projection, Zone 12

\section{EXPLANATION}

GEOLOGY

STREAM ALLUVIUM

BASIN SEDIMENTS

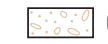

OLDER BASIN SEDIMENTS

CRYSTALLINE AND SEDIMENTARY ROCKS

\section{WATER-LEVEL CHANGE, IN FEET}

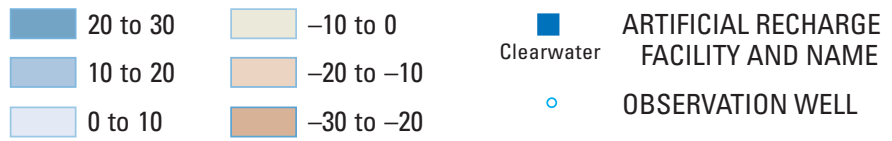

Figure 7. Water-level change in the Tucson Active Management Area: A, Winter 1998 to winter 1999; B, Winter 1999 to winter 2002. 


\section{B. Winter 1999 to winter 2002}

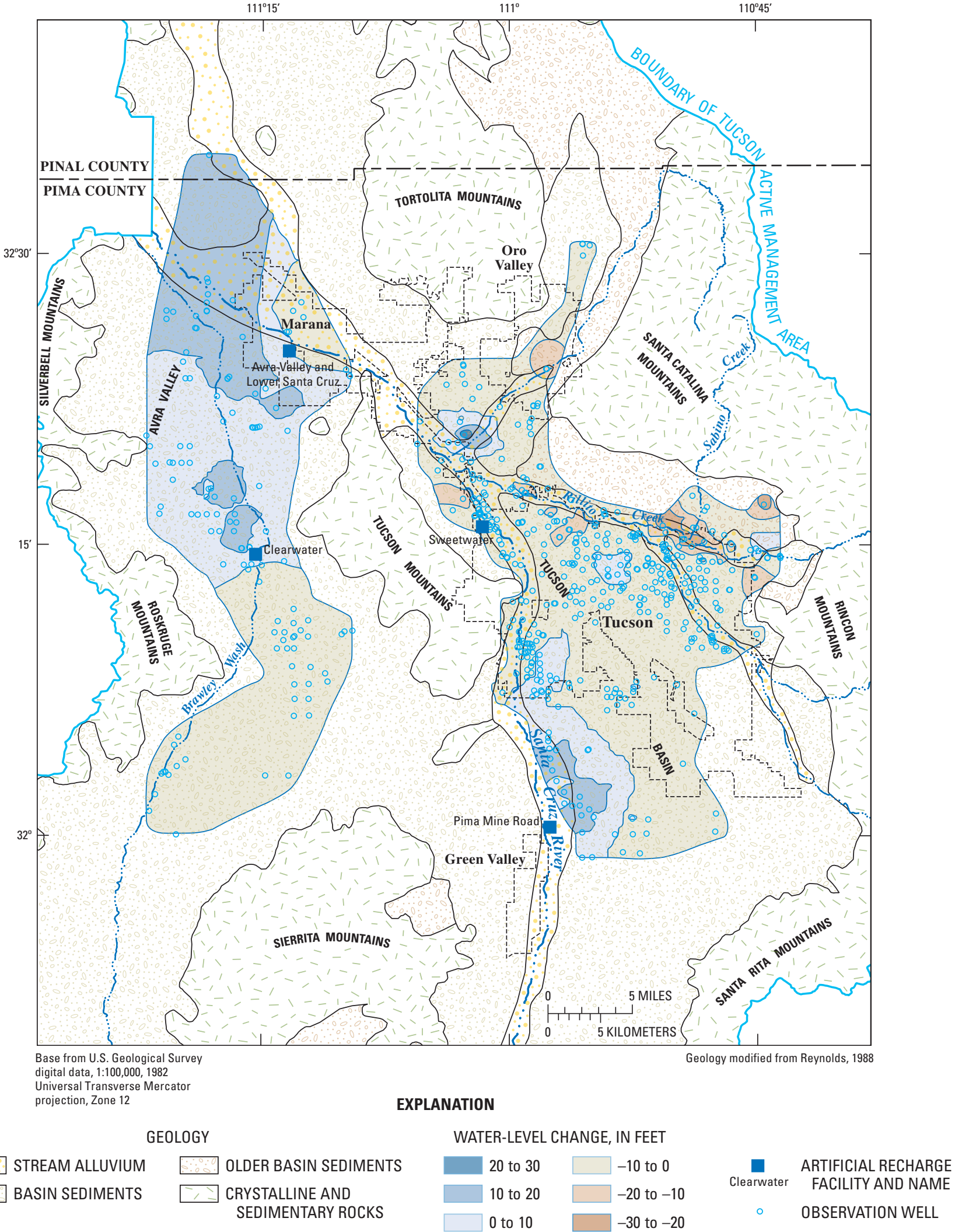

Figure 7. Water-level change in the Tucson Active Management Area: $A$, Winter 1998 to winter 1999; $B$, Winter 1999 to winter 2002-Continued. 


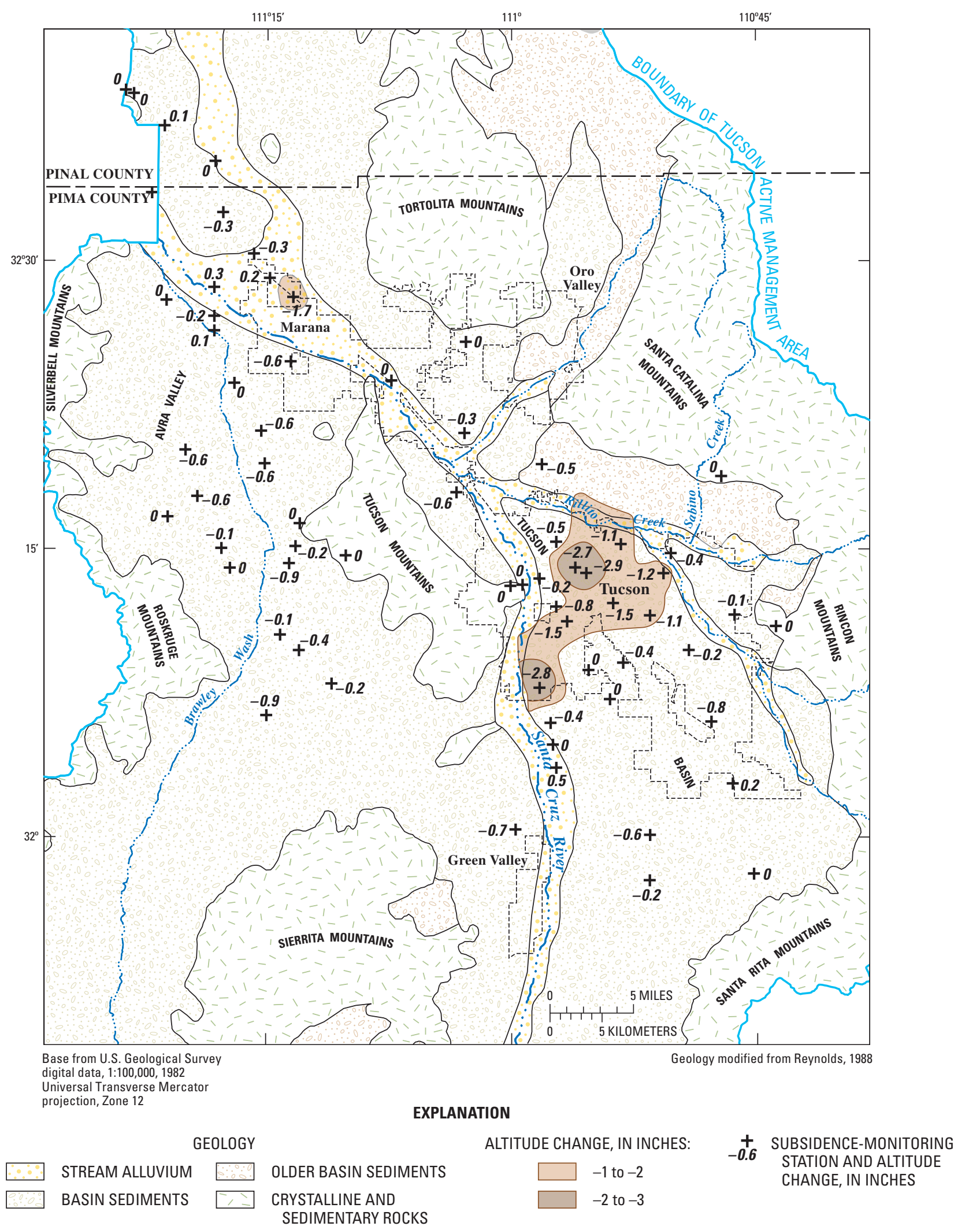

Figure 8. Land subsidence at wells and benchmarks within the Tucson Active Management Area, spring 1999 to spring 2002. 
lute acceleration of gravity measured at control stations and the measured difference in gravity between the control and relative-gravity stations. The initial relative-gravity surveys completed during winter-spring of 1998 lack absolutegravity control because the surveys occurred before the initial absolute-gravity observations during summer 1998. Absolute gravity control for the initial relative-gravity surveys was, therefore, estimated on the basis of trends in later observations. Gravity values for stations were corrected for measured subsidence by using the world-wide average vertical gradient of gravity, $-93 \mu \mathrm{Gal} / \mathrm{ft}$. Local vertical-gravity gradients in subsiding areas may be a few percent less than this average value, but more accurate estimates of vertical-gravity gradients would only marginally improve the accuracy of the subsidence corrections for the observed magnitude of 1-3 in. of subsidence. A subset of stations in the Tucson Basin network was routinely monitored for subsidence. Stations that were not routinely monitored for subsidence include most stations in the Cañada del Oro and Santa Catalina Foothill networks where subsidence has not been documented. All of the stations in suspected subsidence areas were monitored for subsidence.

Results of the annual gravity surveys are displayed as graphs showing gravity change at each station in the regional networks in Tucson basin (fig. 6A) and Avra Valley (fig. 6B). The spatial distribution of gravity change is displayed with maps of storage change across both regional networks during 1998-1999 (fig. 9A) and during 1999-2002 (fig. 9B). The two periods represent the period dominated by gravity increases, 1998-1999, and the period dominated by gravity decreases, 1999-2002. Storage change maps were constructed by inverse distance interpolation of the 1-dimensional storage change $(12.77 \mu \mathrm{Gal} / \mathrm{ft}$ of water) at each station at a grid of $1,641 \mathrm{ft}$ intervals across the study area. Maximum contribution to the gravity signal caused by mass (storage) change outside of the grid cell (the case where the observed storage change is assumed to occur only within the $500 \mathrm{~m}$ grid cell) is about 19 percent assuming storage change occurs at the maximum depth to water in the study area of $500 \mathrm{ft}$. The maximum possible error caused by non-1-dimensional gravity change is much less than 19 percent throughout most of the basin where depths to water are much less than $500 \mathrm{ft}$.

\section{Absolute-Gravity Observations}

Control for monitoring of changes in the acceleration of gravity among the network of relative-gravity stations was established by monitoring the absolute acceleration of gravity at 5 stations. Absolute-gravity control was established at 4 stations in Tucson Basin-TUCSON AA, TUCSON AC, TUCSON AD, and TUCSON AE-and one station in Avra Valley-TUCSON AF (fig.1). Two stations in Tucson Basin were on low-porosity crystalline rock-TUCSON AA (metamorphic) and TUCSON AE (basalt)-where minimal gravity change should occur as a result of storage change in the regional aquifer. The station in Avra Valley, TUCSON
$\mathrm{AF}$, is on low-porosity Cretaceous sandstone. Two stations in Tucson Basin are on alluvial sediments within the extent of the regional aquifer system-TUCSON AC and TUCSON AD. Observed variations in gravity at stations in the alluvial basin were greater than absolute-gravity stations on low-porosity rocks (figs. 6a,b). Gravity values were greatest in July 1998 or spring 1999 at all 5 of the stations, after which gravity generally declined or changed little. Declining gravity trends dissipated by spring 2002 at all 5 stations. Dissipation occurred more quickly at some stations, however, including at TUCSON AE where only the initial measurement in the summer of 1998 was anomalously high.

Gravity trends at absolute-gravity stations that are on the alluvial sediments-TUCSON AD and TUCSON AC-are consistent with winter 1998 recharge and increased groundwater storage along major ephemeral channels followed by redistribution of the recently recharged water. Gravity variations were about $15 \mu \mathrm{Gal}$ at the stations (fig. $6 \mathrm{~A}$ ). Altitude variations did not likely contribute significantly to gravity change at the stations because measured altitude variations near TUCSON AD and at a NGS CORS station (COT2) collocated at TUCSON AC were less than 0.5 in., which would produce a gravity variation of about $4 \mu \mathrm{Gal}$. Gravity at TUCSON $\mathrm{AC}$, which is near Pantano Wash, displayed a declining trend throughout the record that was similar to the water-level trend at nearby well WR-118A. The greatest gravity value at TUCSON AD occurred with the second measurement in spring 1999, which was about $15 \mu \mathrm{Gal}$ greater than the initial value, followed by a slight declining trend. The timing of the gravity response was consistent with a delayed hydrologic response to recharge from winter 1998 along major ephemeral channels that lie at a distance of about 2 miles from the station.

Variations in gravity at stations on low-porosity rock are greater than the observational error of $\pm 2 \mu \mathrm{Gal} \longrightarrow 9 \mu \mathrm{Gal}$ at TUCSON AA and TUCSON AE, and $8 \mu \mathrm{Gal}$ at TUCSON $\mathrm{AF}$, respectively — and may include gravity change caused by several mechanisms, including altitude change, soil-moisture change, or mass change in the adjacent alluvial aquifer. No significant altitude variations are likely to have contributed to gravity variation at the stations because the study area is not tectonically active, and no GPS surveys, including those done for this study, have detected variations in vertical position among the stations. Variations in water content of thin soils on nearby steeply sloping hill slopes or fractures in the crystalline and sedimentary rock may cause short-term variations in gravity near these stations. The wet winter and summer of 1998 could have resulted in short-term storage of a few inches of water in soils and fractures in the crystalline rock. The basalt rock at TUCSON AE is highly fractured and may be especially susceptible to significant variations in moisture content within the fractures. Storage change in the nearby aquifer also could explain a portion of the observed variation at both stations.

The greatest gravity values at TUCSON AA and TUCSON AE occurred with the initial measurement in July 1998 (fig. 6A), which suggest that the anomalously high initial observations may be related to elevated water content in 
Table 1. Positions of ground-water storage monitoring stations in the Tucson Active Management Area and change in ellipsoid height, 1998 to 2002.

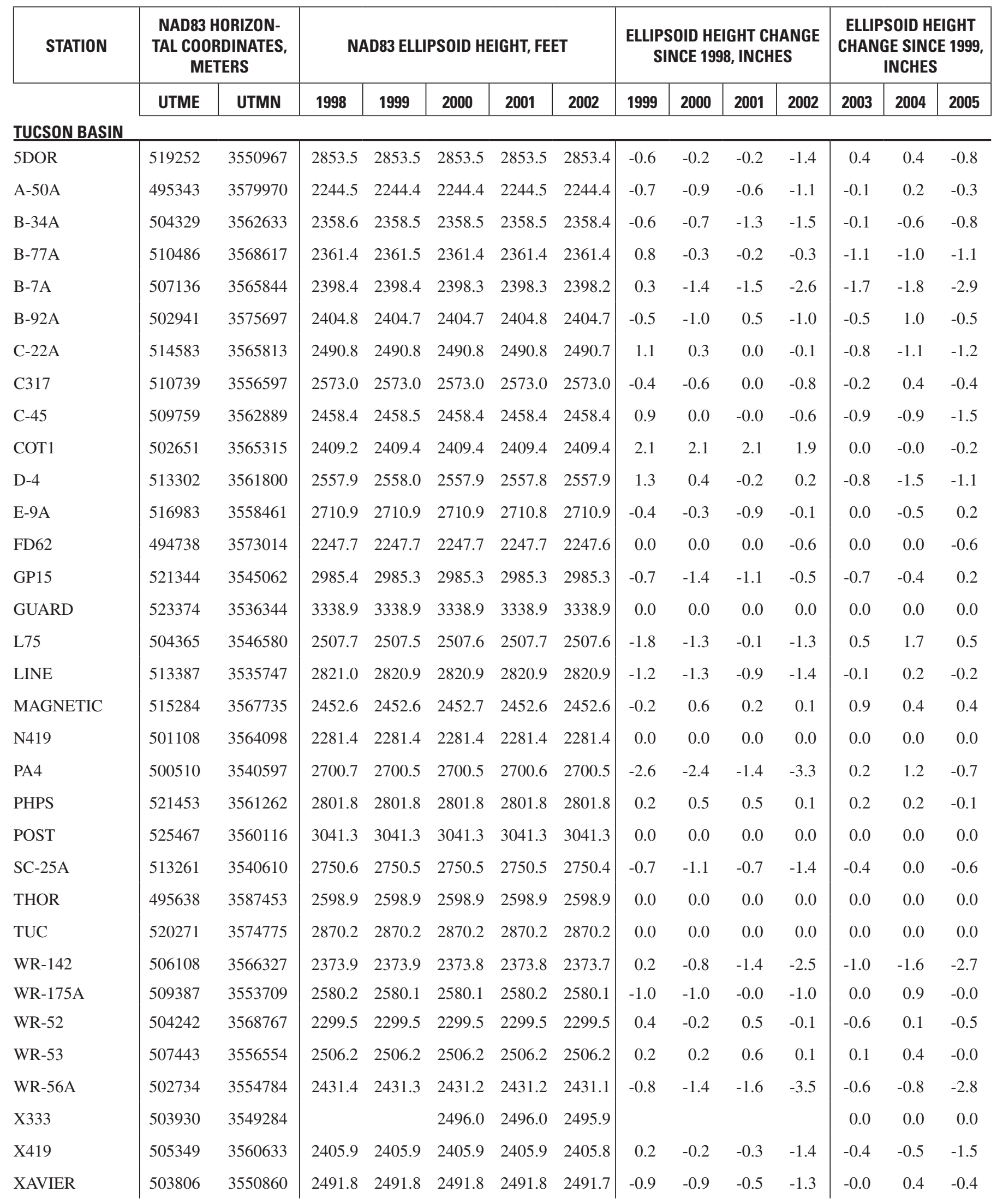


Table 1. Positions of ground-water storage monitoring stations in the Tucson Active Management Area and change in ellipsoid height, 1998 to 2002 - Continued.

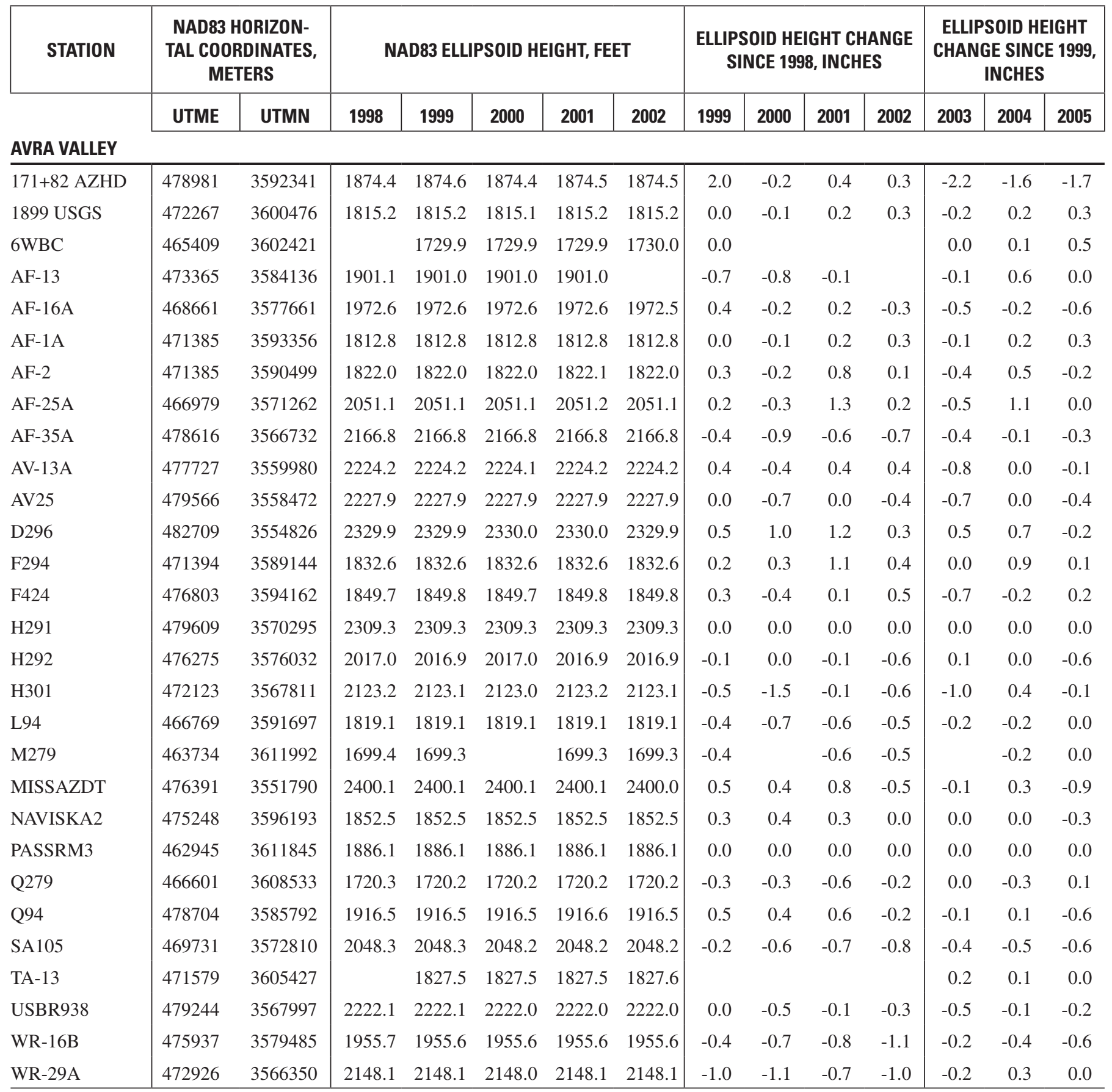


nearby soils and aquifers following the wet winter of 1998 . Subsequent values averaged 4-5 $\mu \mathrm{Gal}$ less than the initial values at both stations and generally varied within the expected range of observational error. Values following the initial measurement at TUCSON AA, however, display a slight declining trend throughout 1998-2002, suggesting that the trend includes a significant component related to long-term processes, such as drainage of the regional aquifer system. Shortterm change in the unsaturated zone water content, however, may have contributed to highest gravity values from 1998 to 1999. Values following the initial measurement at TUCSON AE display no trend suggesting that the elevated initial value was related to short-term processes, such as change in the water content of soils. A two-dimensional estimate of the maximum possible gravity change that can occur at TUCSON $\mathrm{AA}$ as a result of storage change in the adjacent aquifer is about $2 \mu \mathrm{Gal}$. The estimate includes several assumptions, a Sy of 0.25 , the nearest boundary of the aquifer lies at a distance of 1,600 ft from the station, and water-level change at the margin of the aquifer after summer 1998 was about $10 \mathrm{ft}$ on the basis of water-level change at nearby well D-55A (fig. $6 A$ ). Gravity change of $3 \mu \mathrm{Gal}$ could occur at station TUCSON AE as a result of nearby aquifer-storage change on the basis of water-level variation at well SS-016A-located near storage monitoring station N419 (fig. 6Aa). The combined influence of increased soil moisture and increased storage in the nearby aquifer likely resulted in the initial values of absolute gravity at stations on low-porosity rock that were greater than later values.

The greatest gravity value at TUCSON AF occurred with the second measurement, in spring 1999, (fig. 6B), which was about $8 \mu \mathrm{Gal}$ greater than the measured value in the summer of 1998 and 4 to $7 \mu \mathrm{Gal}$ greater than a slight declining gravity trend that occurred with subsequent measurements. The magnitude of the variation suggests that the underlying sedimentary rock is sufficiently porous that significant local variations in soil moisture or aquifer storage occur. The occurrence of the greatest gravity values following the summer of 1998 suggests that the variations may have resulted from redistribution of water that infiltrated along a nearby stream channel during the previous year.

\section{Tucson Basin}

Annual relative-gravity surveys of the ground-water storage monitoring network, including the absolute-gravity control stations, in Tucson Basin resulted in gravity trends (fig. 6a) that were similar to the trends at absolute-gravity stations on alluvium. Absolute-gravity values for the initial relative-gravity survey were estimated by assuming that the winter 1998 absolute-gravity values at stations located on crystalline rock-TUCSON AA and TUCSON AEwere equivalent to values surveyed during spring 2001. This assumption implies that winter 1998 precipitation and recharge resulted in a gravity increase from December 1997 to summer 1998 of $6 \mu \mathrm{Gal}$ at TUCSON AA and $7 \mu \mathrm{Gal}$ at TUCSON AE.

Many stations in Tucson Basin monitoring network displayed increases in gravity during 1998-2000 followed by no trend or declining trends (fig. 6A). Increases in gravity generally were greatest and occurred sooner at stations near the major ephemeral streams-Rillito Creek, Santa Cruz River, Cañada del Oro Wash, Sabino Creek, Pantano Wash, and Pima Wash. The greatest variations occurred at stations B-92A $(60 \mu \mathrm{Gal}$ near PIMA WASH), A-54A (40 $\mu \mathrm{Gal}$ near Rillito Creek), B-77A (40 $\mu$ Gal near Rillito Creek), FD62 (60 $\mu \mathrm{Gal}$ near the Santa Cruz River). Large variation also occurred near major centers of ground-water withdrawal, such as near station A-50A $(60 \mu \mathrm{Gal})$. Significant gravity variation (10-20 $\mu \mathrm{Gal})$ occurred at a few stations that lie at great distance from major ephemeral streams (E-9A, POST, 5DOR, PA4, LINE, GUARD, GPS115); however, no clear trend in gravity was evident at these stations.

The spatial distribution of storage change in Tucson Basin from winter 1998 to winter 1999 (fig. 9A) displays increased storage near major ephemeral channels that resulted from streamflow infiltration. During the period, storage increases of 0-2 ft of water occurred throughout most of Tucson Basin. Increases of 2-4 ft of water primarily occurred near parts of major ephemeral channels, including Rillito Creek, Santa Cruz River, and Cañada del Oro Wash. Storage loss primarily occurred in the northwestern part of Tucson Basin. Storage loss of 0-2 ft of water occurred along the lower reaches of Cañada del Oro Wash. More than $2 \mathrm{ft}$ of storage loss occurred near the Tortolita Mountains.

The spatial distribution of storage change in Tucson Basin from winter 1999 to winter 2002 (fig. 9B) reflects the redistribution of the water that recharged during the previous year throughout a greater region of the aquifer. The period was dominated by storage loss, indicating ground-water withdrawals exceeded recharge across most of the basin. Dissipation of a recharge mound that had developed near major ephemeral channels during the previous year resulted in the greatest storage loss near the channels. Storage loss of 2 to $8 \mathrm{ft}$ occurred near Rillito Creek, Lower Cañada del Oro Wash, and along the lower reach of the Santa Cruz River in Tucson Basin. Storage loss of 0-2 ft of water near the Tortolita Mountains was a continuation of the preexisting trend. Storage loss of 0-2 ft also occurred across a large portion of the southern Tucson Basin. Storage increases of $0-2 \mathrm{ft}$ near the southern reach of the Santa Cruz River, and in some areas near the Santa Catalina Mountains, was a continuation of the previous trend. Much of the increased storage in these areas likely resulted from recharge that occurred with precipitation and streamflow from summer of 1999 and fall 2000 and nearby artificial recharge.

\section{Avra Valley}

Surveys of the relative-gravity station network in Avra Valley generally were completed during May of 1998, 1999, 


\section{A. 1998 to 1999}

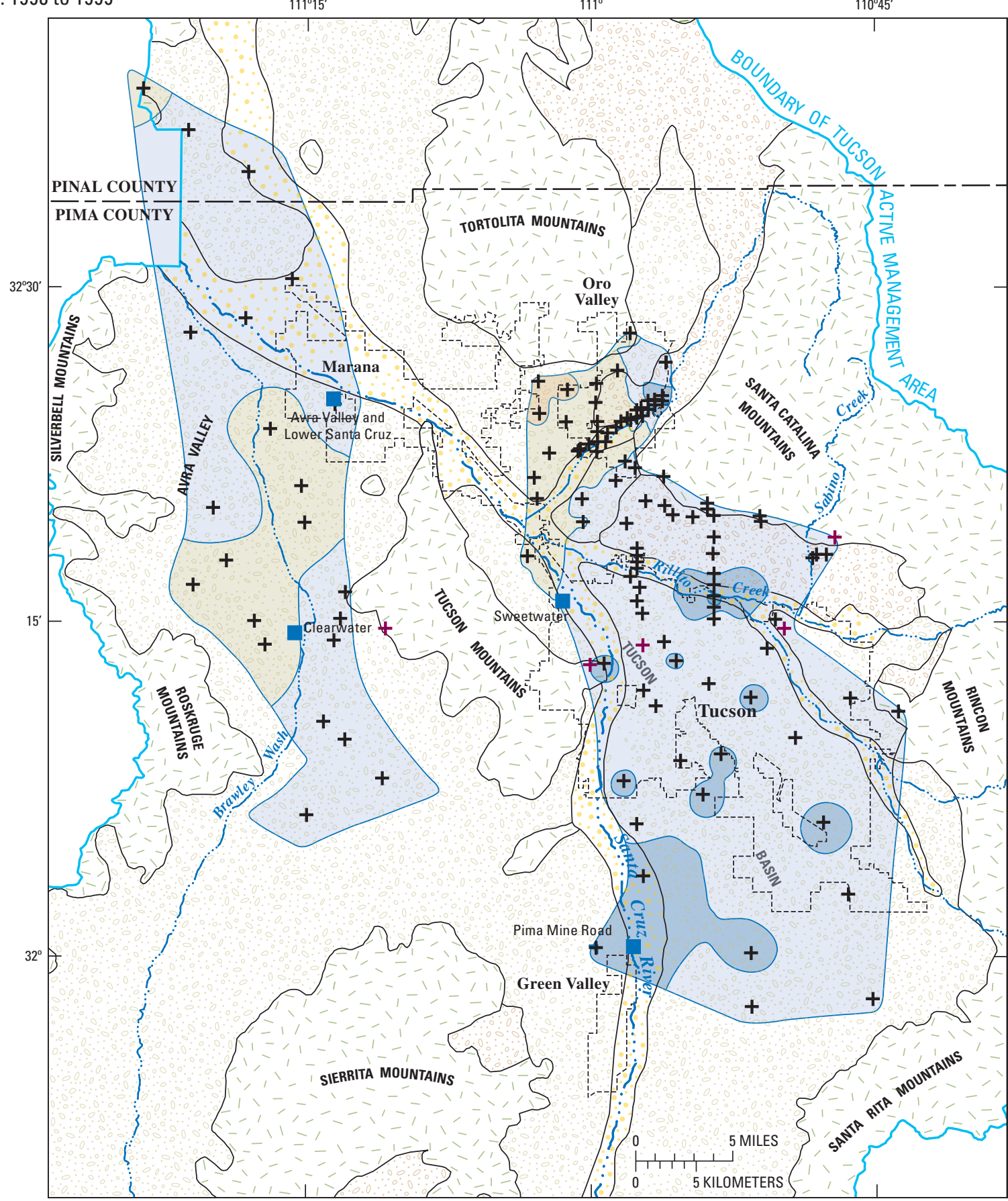

Base from U.S. Geological Survey digital data, 1:100,000, 1982

Universal Transverse Mercator projection, Zone 12

EXPLANATION

GEOLOGY

\begin{tabular}{|c|c|}
\hline$\cdots$ & STREAM ALLUVIUM \\
\hline$\square$ & BASIN SEDIMENTS \\
\hline & OLDER BASIN SEDIMENTS \\
\hline & $\begin{array}{l}\text { CRYSTALLINE AND } \\
\text { SEDIMENTARY ROCKS }\end{array}$ \\
\hline
\end{tabular}

GROUND-WATER STORAGE CHANGE, IN FEET:

\begin{tabular}{|c|c|c|c|}
\hline 6 to 8 & 2 to 4 & -2 to 0 & -6 to -4 \\
\hline 4 to 6 & 0 to 2 & -4 to -2 & -8 to -6 \\
\hline
\end{tabular}

$+\quad$ GRAVITY STATION

$+\quad$ abSOLUTE GRAVITY STATION

Clearwater ARTIFICIAL RECHARGE FACILITY AND NAME

Figure 9. Ground-water storage change in the Tucson Active Management Area, winter 1998 to winter 2002 in the Tucson Basin and spring 1998 to spring 2002 in Avra Valley: A, 1998 to 1999; B, 1999 to 2002. 


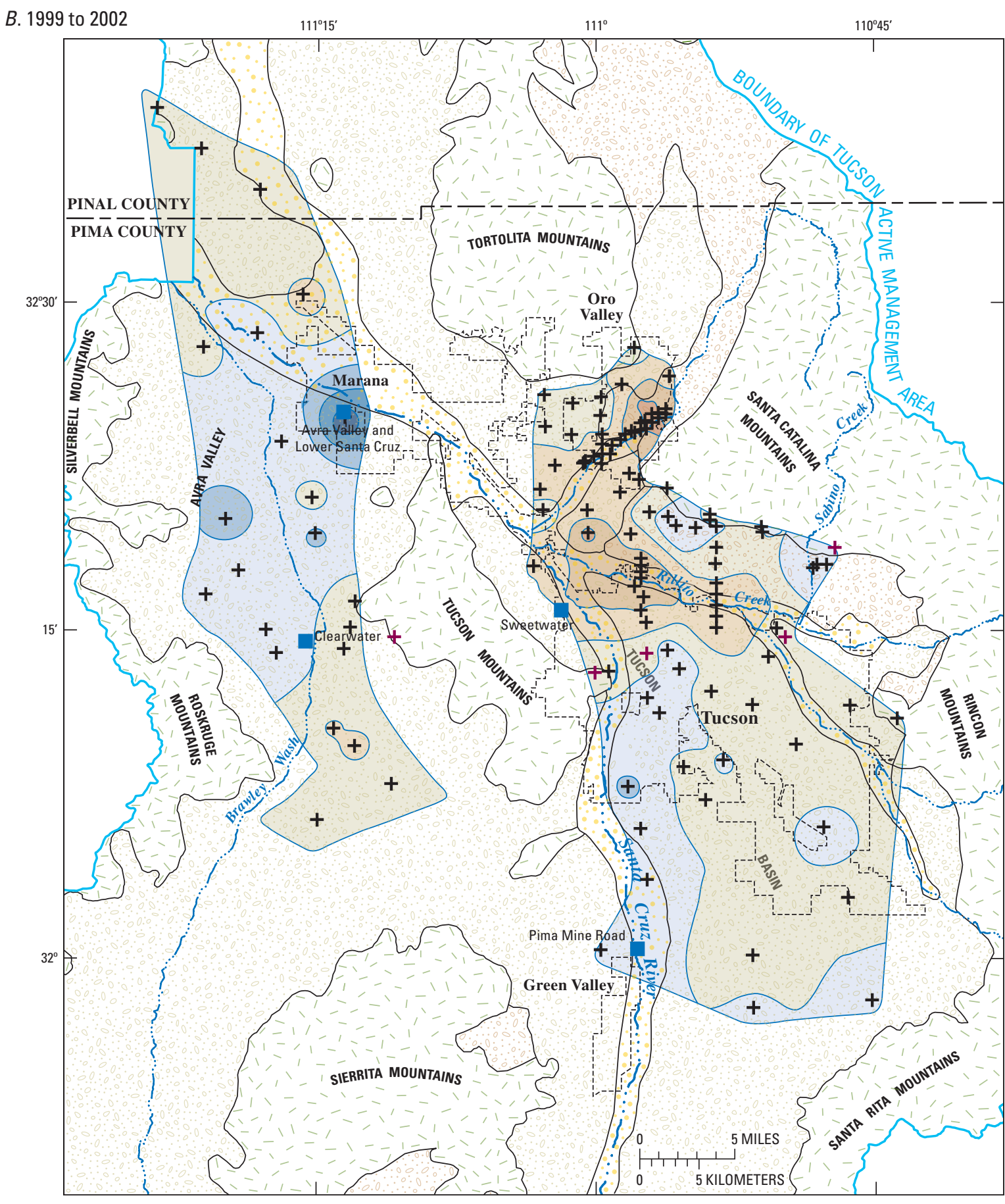

Base from U.S. Geological Survey digital data, 1:100,000, 1982

Universal Transverse Mercator projection, Zone 12

EXPLANATION

GEOLOGY

\begin{tabular}{|ll}
\hline & STREAM ALLUVIUM \\
\hline 0 & BASIN SEDIMENTS \\
\hline$\quad$ & OLDER BASIN SEDIMENTS \\
& CRYSTALLINE AND \\
& SEDIMENTARY ROCKS
\end{tabular}

GROUND-WATER STORAGE CHANGE, IN FEET:

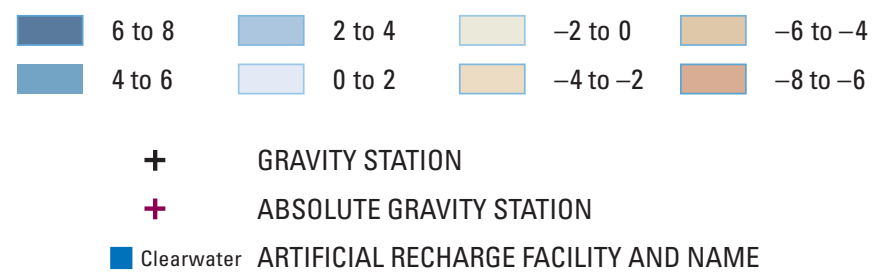

Figure 9. Ground-water storage change in the Tucson Active Management Area, winter 1998 to winter 2002 in the Tucson Basin and spring 1998 to spring 2002 in Avra Valley: A, 1998 to 1999; B, 1999 to 2002_Continued. 
2000, 2001, and 2002. Many stations also were surveyed during January 1998. Equipment repairs delayed the 2001 survey until September. All relative-gravity stations were referenced to the absolute-gravity station TUCSON AF. The reference absolute-gravity value at TUCSON AF for the winter and spring 1998 network surveys was assumed to be equivalent to the value observed during summer 1998 because both the surveys and the absolute-gravity observation occurred after the wet winter in 1998. Gravity variations at TUCSON AF generally are within the observational error except for the value that was observed in winter 1999, which was greater than preceding and subsequent observations by $8 \mu \mathrm{Gal}$ and $5 \mu \mathrm{Gal}$, respectively.

Annual surveys of the monitoring network in Avra Valley resulted in overall gravity trends (fig. $6 B$ ) that were notably different than those in Tucson Basin. No trends are evident at many stations in Avra Valley; however, two major trends can be identified. Some trends in gravity at Avra Valley stations were similar to measured trends in Tucson Basin where the greatest gravity values tended to occur in spring 1999. The greatest gravity values at stations occurred in spring 1999 followed by gradual declines of 10-30 $\mu \mathrm{Gal}$ from spring 1999 to 2002, including at stations NAVISKA2, AF-16A, H291, TUCSON AF, AF-35A, AV-13A, and AF-25. This trend was similar to gravity trends in Tucson Basin that likely represent delayed aquifer-system response to recharge along ephemeral stream channels during winter 1998 followed by declining gravity in areas of intense ground-water pumpage. The other major trend was increasing gravity at stations near the Santa Cruz River and artificial recharge facilities. Increases in gravity from spring 1999 to spring 2002 of as much as 25 $\mu \mathrm{Gal}$ occurred at stations near an artificial recharge facility in central Avra Valley-H292, SA105, AF-25A, H301, WR29A. The greatest increase in gravity of $90 \mu \mathrm{Gal}$ occurred at station Q94, which is near an artificial recharge facility near Marana and the Santa Cruz River. Small increases in gravity from spring 1999 to spring 2002, less than $15 \mu \mathrm{Gal}$, occurred at other stations near the Santa Cruz River including at stations L94, AF-1A, TA-13, and Q279. Only a few stations, mainly in southern Avra Valley, displayed overall decreases in gravity where the decline likely resulted from locally intense pumping in a municipal well field.

The spatial distribution of storage change in Avra Valley from spring 1998 to spring 1999 (fig. 9A) displays the distribution of recharge during the period that was greater than ground-water withdrawals. Increase in ground-water storage of less than $2 \mathrm{ft}$ of water occurred across most of the basin with the exception of a few stations near the middle part of the basin where storage losses of less than $2 \mathrm{ft}$ of water occurred. The lack of greater increases in storage near the Santa Cruz River and Brawley Wash may be an artifact of the lack of stations near the ephemeral channels.

Storage change in Avra Valley from spring 1999 to spring 2002 (fig. 9B) included increases in storage near artificialrecharge facilities, storage losses near centers of ground-water withdrawal, and redistribution of stored water that recharged during the previous year. The overall distribution of storage change was nearly the reverse of the changes that occurred from spring 1998 to spring 1999. Increases in storage occurred near recharge facilities in central Avra Valley, where increases of 0-2 ft occurred at several stations, and near Marana, where increases of as much as $8 \mathrm{ft}$ of water occurred at station Q94. Decreases in storage of 0-2 ft of water primarily occurred north of the Santa Cruz River and in the southern part of Avra Valley, an area that includes a municipal well field. The apparent reversal of the distribution of change relative to the spring 1998 to spring 1999 period may be related to redistribution of storage following recharge during the previous period.

\section{Gravity and Water-Level Correlation}

Changes in gravity were correlated with water-level altitudes in wells for the purpose of estimating Sy at 37 pairs of gravity stations and wells-25 in Tucson Basin and 12 in Avra Valley — by using data collected from summer 1998 to fall 2002 (table 2). Earlier data at many wells were not included in the analysis because of a lack of absolute-gravity control. Correlations were variable and illustrate the complex nature of both water levels in wells and ground-water storage change. Specific yield at wells was estimated as the ratio of change in the gravity-based estimate of stored water to water-level altitude change. The gravity change was converted to an equivalent thickness of change in water stored in the subsurface by using the infinite slab approximation of $12.77 \mu \mathrm{Gal} / \mathrm{ft}$ of water. Estimates of Sy at many stations were uncertain because variations in gravity or water level were small, poorly correlated, or inversely correlated.

Good positive correlation of gravity and water-level altitude change was indicated by correlation coefficients of 0.75 or greater at 18 of the 37 monitored sites. Negative correlation occurred at 7 sites, and poor to moderate positive correlation occurred at 11 sites. Estimates of Sy ranged from 0.01 to 1.18 and averaged 0.28 for the 30 sites that displayed a positive correlation of gravity and water-level altitude change. The maximum possible values of Sy are limited by total porosity and specific retention. The maximum porosity for alluvial materials ranges from 48 percent for sand to as much as 90 percent for swelling (compressible) clays (de Marsily, 1986). However, retention of water limits specificyield values of alluvial aquifers to generally less than about 0.32 , except for compressible aquifers. Sy values of greater than 0.32 that are derived from these data probably result from contributions to gravity change that are caused by storage loss in the unsaturated zone or perched aquifers following infiltration during the wet winter of 1998. Contributions to Sy values from compressible portions of the aquifer are minimal based on observed land subsidence of less than $3 \mathrm{in}$., which is equivalent to 3 in. of water released from storage in compressible portions of the aquifer. The 2 greatest Sy values, 0.73 and 1.18 , occurred at wells MW10 and B-92A, respectively, and 
Table 2. Correlation of gravity and water-level change and estimates of specific yield at wells in the Tucson Active Management Area, 1998 to 2002.

[Light shading indicates good positive correlation of water level and gravity change. Dark shading indicates negative correlation of water level and gravity change. Cells with dark boundaries indicate that a portion of the gravity change likely results from storage change in the unsaturated zone due to streamflow infiltration in an ephemeral channel.]

\begin{tabular}{|c|c|c|c|c|c|c|}
\hline $\begin{array}{l}\text { MONITORING } \\
\text { NETWORK }\end{array}$ & WELL & $\begin{array}{l}\text { GRAVITY } \\
\text { STATION }\end{array}$ & $\begin{array}{l}\text { SPECIFIC } \\
\text { YIELD }\end{array}$ & CORR. COEF. & $\begin{array}{l}\text { WATER-LEVEL } \\
\text { RANGE, FT. }\end{array}$ & $\begin{array}{l}\text { STORAGE RANGE, } \\
\text { FT. of WATER }{ }^{10}\end{array}$ \\
\hline \multirow[t]{26}{*}{ Tucson Basin } & WR-52 & WR-52 & 0.11 & 0.99 & 19.6 & 4.0 \\
\hline & B-92A & B-92A & 1.18 & 0.98 & 3.4 & 5.7 \\
\hline & WR-175A & WR-175A & 0.55 & 0.97 & 2.9 & 1.6 \\
\hline & WR-118A ${ }^{1}$ & $\begin{array}{l}\text { TUCSON } \\
\text { AC }\end{array}$ & 0.21 & 0.96 & 4.4 & 1.1 \\
\hline & $\mathrm{C}-22 \mathrm{~A}$ & $\mathrm{C}-22 \mathrm{~A}$ & 0.25 & 0.96 & 6.9 & 1.8 \\
\hline & C-45 & C- 45 & 0.26 & 0.94 & 10.6 & 2.9 \\
\hline & A-54A & A-54A & 0.27 & 0.94 & 15.2 & 4.7 \\
\hline & B- $001 A^{2}$ & $\begin{array}{c}\text { TUCSON } \\
\text { AD }\end{array}$ & 0.35 & 0.92 & 2.0 & 0.7 \\
\hline & A-50A & A-50A & 0.49 & 0.91 & 11.3 & 4.1 \\
\hline & MW10 & MW10 & 0.73 & 0.94 & 11.7 & 8.6 \\
\hline & C-99A & MW6 & 0.52 & 0.89 & 8.8 & 4.4 \\
\hline & MW13 & MW13 & 0.35 & 0.87 & 12.2 & 4.3 \\
\hline & MW5 & MW5 & 0.44 & 0.85 & 9.3 & 4.3 \\
\hline & CI-067A & MW4 & 0.67 & 0.77 & 6.0 & 3.5 \\
\hline & A- $049 A^{3}$ & FD62 & 0.04 & 0.55 & 29.5 & 2.6 \\
\hline & D-4 & D-4 & 0.13 & 0.54 & 7.2 & 1.9 \\
\hline & SC-17A ${ }^{4}$ & XAVIER & 0.05 & 0.52 & 6.7 & 0.7 \\
\hline & B-77A & B-77A & 0.13 & 0.40 & 16.8 & 5.3 \\
\hline & E-9A & E-9A & 0.12 & 0.38 & 2.8 & 1.6 \\
\hline & WR-53 & WR-53 & 0.09 & 0.29 & 3.4 & 0.9 \\
\hline & SC-005A ${ }^{5}$ & L75 & 0.01 & 0.21 & 14.1 & 0.8 \\
\hline & SC-25A & SC-25A & -0.10 & -0.46 & 8.6 & 2.1 \\
\hline & B- $76^{6}$ & X419 & -0.08 & -0.63 & 9.0 & 1.2 \\
\hline & WR-147A7 & MAGNETIC & -0.43 & -0.78 & 2.4 & 1.3 \\
\hline & WR-142A & WR-142A & -0.46 & -0.86 & 7.5 & 3.7 \\
\hline & B-7A & B-7A & -0.11 & -0.97 & 6.8 & 0.7 \\
\hline
\end{tabular}

are not representative of the aquifer because the wells are near major ephemeral-stream channels where large gravity changes are likely caused by nearby streamflow infiltration and significant changes in unsaturated-zone storage.

The estimated Sy for the 27 sites that resulted in positive correlation and were not near major ephemeral channels ranged from 0.07 to 0.67 and averaged 0.21 . Many sites displayed minimal variation in water level, however, resulting in a low correlation coefficient and Sy estimates that are not reliable. The estimated Sy at 10 sites that also had large water-level variations of $8 \mathrm{ft}$ or more, ranged from 0.01 to 0.52 and averaged 0.27 . Very large Sy values of greater than 0.35 occurred at 3 of the 10 sites that had water-level variations of $8 \mathrm{ft}$ or more, were not near major ephemeral channels, and had positive correlation coefficients of 0.75 or greater. A large range of storage variation, more than $4 \mathrm{ft}$ of water, occurred at these 3 stations suggesting that delayed drainage of the aquifer or unidentified perched aquifers may occur.

Water levels in several wells likely represent confined ground-water conditions on the basis of large water-level changes that were accompanied by little storage change. Water-level recovery of $30.3 \mathrm{ft}$ and $35.6 \mathrm{ft}$ at wells AF-13 and AF-14, respectively, occurred with storage change of less 
Table 2. Correlation of gravity and water-level change and estimates of specific yield at wells in the Tucson Active Management Area, 1998 to 2002-Continued.

[Light shading indicates good positive correlation of water level and gravity change. Dark shading indicates negative correlation of water level and gravity change. Cells with dark boundaries indicate that a portion of the gravity change likely results from storage change in the unsaturated zone due to streamflow infiltration in an ephemeral channel.]

\begin{tabular}{|c|l|l|c|c|c|c|}
\hline $\begin{array}{c}\text { MONITORING } \\
\text { NETWORK }\end{array}$ & \multicolumn{1}{|c|}{ WELL } & \multicolumn{1}{|c|}{$\begin{array}{c}\text { GRAVITY } \\
\text { STATION }\end{array}$} & $\begin{array}{c}\text { SPECIFIC } \\
\text { YIELD }^{9}\end{array}$ & CORR. COEF. & $\begin{array}{c}\text { WATER-LEVEL } \\
\text { RANGE, FT. }\end{array}$ & $\begin{array}{c}\text { STORAGE RANGE, } \\
\text { FT. of WATER }^{\text {10 }}\end{array}$ \\
\hline Avra Valley & AV-13A & AV-13A & 0.12 & 0.98 & 11.1 & 2.2 \\
& AF-35A & AF-35A & 0.07 & 0.96 & 18.3 & 1.4 \\
& AV-25 & AV-25 & 0.07 & 0.78 & 23.3 & 2.4 \\
& WR-29A & WR-29A & 0.19 & 0.75 & 6.9 & 2.1 \\
& AF-25A & AF-25A & 0.18 & 0.50 & 3.5 & 2.0 \\
& AF-148 & AF-13 & 0.01 & 0.39 & 30.3 & 0.8 \\
& AF-13 & AF-13 & 0.01 & 0.37 & 35.6 & 0.8 \\
\cline { 2 - 7 } & AF-1A & AF-1A & 0.03 & 0.34 & 15.3 & 1.9 \\
\cline { 2 - 7 } & AF-16A & AF-16A & 0.03 & 0.19 & 6.5 & 1.6 \\
& TA-13 & TA-13 & -0.12 & -0.10 & 0.1 & 1.9 \\
& WR-16B & WR-16B & -0.25 & -0.64 & 2.1 & 1.2 \\
\hline
\end{tabular}

${ }^{1}$ Well WR-118A is about $1000 \mathrm{ft}$ from gravity station TUCSON AC.

${ }^{2}$ Well B-001A is about $3500 \mathrm{ft}$ from gravity station TUCSON AD.

${ }^{3}$ Well B-049A is about $3600 \mathrm{ft}$ from gravity station FD62.

${ }^{4}$ Well SC-17A is about $200 \mathrm{ft}$ from gravity station XAVIER.

${ }^{5}$ Well SC-005A is about $600 \mathrm{ft}$ from gravity station L75.

${ }^{6} \mathrm{Well} \mathrm{B}-76$ is about $50 \mathrm{ft}$ from gravity station $\mathrm{X} 419$.

${ }^{7}$ Well WR-147A is about $200 \mathrm{ft}$ from gravity station MAGNETIC.

${ }^{8} \mathrm{Well}$ AF-14 is about $200 \mathrm{ft}$ from gravity station AF-13.

${ }^{9}$ Specific yield calculated as the slope of the water-level elevation and storage relation.

${ }^{10}$ Storage change calculated using the infinite slab approximation, 12.77 microgal per foot of water.

than $1 \mathrm{ft}$ of water at nearby storage monitoring station AF-13 resulting in a Sy estimate of less than 0.01 at both wells. Water-level recovery of about $15 \mathrm{ft}$ was accompanied by a poorly correlated storage-change correlation coefficient of 0.34 , of about $2 \mathrm{ft}$ of water at well AF-1A suggests that the water-level change represents confined ground-water conditions at this well, which is not far from wells AF-13 and AF-14. A low Sy estimate of 0.01 at well SC-005A resulted from water-level and storage changes of $14 \mathrm{ft}$ and less than 1 $\mathrm{ft}$ of water, respectively.

Negative correlations of water-level altitudes and storage change at 7 sites are primarily related to a lack of significant water-level change, less than $10 \mathrm{ft}$. Significant changes in storage of 1-4 ft of water at many of these sites suggest, however, that the water-level changes in the wells may not be representative of overall ground-water storage change near the sites. Many of the wells are in or near regions of perched aquifers, including wells B-76, SC-25A, and B-7A. Changes in unsaturated zone water content are likely at well WR-

$142 \mathrm{~A}$, which is at an irrigated city park and where nearly $4 \mathrm{ft}$ of change in water storage occurred.

The range of relations between water-level and storage trends at wells within the monitored portion of the TAMA reflects the complex nature of the ground-water flow system and illustrates the uncertainty of storage change estimates that are based on water-level change. Ground-water storage change in the study area occurs in a complex aquifer system that includes confined and unconfined aquifers and perched unconfined aquifers with spatially variable storage properties. Water levels in wells may represent hydraulic head in any single aquifer, or may represent a hydraulic head that is a composite of multiple aquifers. Knowledge of the subsurface lithology and well construction, specifically screened intervals, are needed to determine hydrogeologic conditions that are represented by water levels in each well. The repeat gravity surveys used in this investigation monitor the total subsurface-storage change and aquifer-storage change at wells where variations in soil moisture are negligible or known. Positive correlation of significant water-level change and gravity-derived estimates of storage change will occur only where water levels are representative of a single aquifer and where the range of water-level variation spans a portion of the aquifer that has approximately uniform storage properties. 


\section{Ground-Water Budget}

Ground-water budgets were estimated for the monitored period, winter 1998 to spring 2002, within the region of monitored ground-water storage in Tucson Basin and Avra Valley. Estimated components of the ground-water budget include storage change, outflow from the ground-water system, and inflow to the ground-water system. Storage change was estimated from integration of the gravity change by using the excess mass equation (Telford, 1976) across the two networks of monitoring stations in Tucson Basin and Avra Valley. Outflow from the ground-water system includes ground-water withdrawals, evapotranspiration, and ground-water outflow across boundaries of the monitored area. Annual ground-water withdrawals were available for December 1997 through 1999 from a ground-water flow model of the TAMA developed by the ADWR (Mason and Bota, 2006). Rates of ground-water withdrawal during 2000 and 2001 were estimated to be the same as 1999 withdrawal rates on the basis of very little reported change (Tucson AMA Trends and Patterns, accessed May 12, 2006, at http://www.azwater. gov/WaterManagement_2005/Content/AMAs/TucsonAMA/ TAMA_documents/TAMA_Trends_and_Patterns.ppt). Estimates of evapotranspiration and ground-water outflow were based on analyses of Hanson and Benedict (1994) and Hanson and others (1990). Inflow to the ground-water system includes ground-water flow across boundaries and recharge from natural, artificial, and incidental sources, including effluent within the monitored regions. Reported artificial recharge was available from the TAMA [Arizona Water Banking Authority (AWBA) Activity in the Tucson AMA, 2005, accessed December 10, 2007, at http://www.azwater.gov/WaterManagement_2005/Content/AMAs/TucsonAMA/TAMA_documents/TAMA_AWBA_ Summary.pdf]. Effluent recharge was estimated on the basis of measured effluent released to the Santa Cruz River and effluent gaged at two stations downstream from the sewage-treatment plants-Santa Cruz River at Cortaro Road and Santa Cruz River at Trico Road. Other incidental recharge estimates were derived from Mason and Bota (2006). Inflow to the monitored regions from natural recharge, including ground-water inflow from adjacent unmonitored regions, was estimated by using water balance methods as a residual of the monitored or estimated groundwater budget components of storage change, ground-water outflow, and artificial and incidental recharge.

Each estimate of a water-budget component includes error. Outflow from the ground-water system includes errors that are caused primarily by inaccurate measurements of ground-water withdrawals and ground-water outflow. Estimated ground-water withdrawals rely on accurate reporting of withdrawals by major private and municipal (public) water purveyors, and estimates of withdrawals by small well users. Ground-water outflow is difficult to estimate accurately, but the error is likely insignificant in comparison to errors in ground-water withdrawals. Estimates of total ground-water outflow can be expected to approximate the true outflow within about 30 percent. Artificial recharge is well monitored, and errors are assumed insignificant in comparison to the estimated error of other water budget components. Incidental recharge is difficult to estimate but also is assumed to be insignificant in comparison to the estimated error of other waterbudget components. Errors in the estimated ground-water storage change are caused by imprecise gravity measurements and imprecise estimates of storage change in areas between monitoring stations. Total error in estimates of ground-water storage change can be approximated as the residual of errors in relative gravity measurements, less than about $5 \mu \mathrm{Gal}$, and errors in the measurement of absolute gravity, about $2 \mu \mathrm{Gal}$, which is about $0.4 \mathrm{ft}$ of water. Total error in the estimated storage change is calculated by integration of the estimated error for each storage-monitoring network. Estimated error for Tucson Basin, Avra Valley, and the combined networks is 110,000 acre-ft, 80,000 acre-ft, and 140,000 acre-ft, respectively, Total error in estimated natural recharge and total recharge is the residual of the error in estimated ground-water outflow and storage change for each network, or 160,000 acre-ft, 110,000 acre-ft, and 190,000 acre-ft, for Tucson Basin, Avra Valley, and the combined networks, respectively.

\section{Tucson Basin}

Ground-water budgets for the monitored region in Tucson Basin were estimated for periods between surveys that were completed during December 1997, February 1999, February 2000, May 2001, and February 2002 (table 3, fig. 10). The first period was dominated by increases in gravity at most stations relative to bedrock control stations indicating a significant increase in ground-water storage. Ground-water storage increased 200,000 acre-ft during the first year of monitoring and declined from February 1999 to February 2002 to about the conditions of December 1997. Ground-water outflow, including about 2,500 acre-ft per year of outflow to Avra Valley (Hanson and Benedict, 1994) ranged from 110,000 to 210,000 acre-ft between annual surveys and averaged about 160,000 acre-ft per year during the 4 years of monitoring. Artificial and incidental recharge totaled about 60,000 acre-ft during the monitoring period. Natural recharge varied from 380,000 acre-ft during the initial period to an average rate of 70,000 acre-ft per year from February 1999 to February 2002. Monitoring of a detailed gravity-station network and streamflow along a large portion of Rillito Creek indicate that recharge along the channel was about 40,000 acre-ft during winter 1998 and about 4,000 acre-ft from 1999 to 2000 (Pool, 2005). Negative recharge estimates for the period February 2000 to May 2001 are within the range of error of the estimates. Minimal recharge from February 2000 to May 2001 is supported by a lack of increases in gravity and water levels at wells during the period.

\section{Avra Valley}

Ground-water budgets for the monitored region in Avra Valley were estimated for periods between surveys completed 
during May 1998, May 1999, April 2000, September 2001, and May 2002 (table 3, fig. 10). Ground-water storage in Avra Valley increased 70,000 acre-ft during the monitoring period. Storage losses of 60,000 acre-ft occurred from May 1999 to April 2000 and losses of 80,000 acre-ft occurred from September 2001 to May 2002. Total ground-water discharge including about 18,500 acre-ft per year of ground-water outflow (Hanson and others, 1990) and ground-water withdrawals averaged about 80,000 acre-ft per year during the monitoring period. Artificial and incidental recharge in Avra Valley totaled about 260,000 acre-ft during the monitoring period. Natural recharge rates varied greatly with most recharge occurring from May 1998 to May 1999 and April 2000 to September 2001 at volumes of 80,000 acre- $\mathrm{ft}$ and 140,000 acre-ft, respectively. The high rate of recharge from April 2000 to September 2001 may be overestimated because of under sampling of the distribution of storage change near a recharge facility in north Avra Valley. Large storage change at station Q94 (fig. 6B), which is near the recharge facilities and the Santa Cruz River, was much greater than any nearby station resulting in possible overestimation of storage change in the intervening regions. Apparent negative rates of natural recharge from May 1999 to April 2000 and September

\section{A. Tucson Basin}

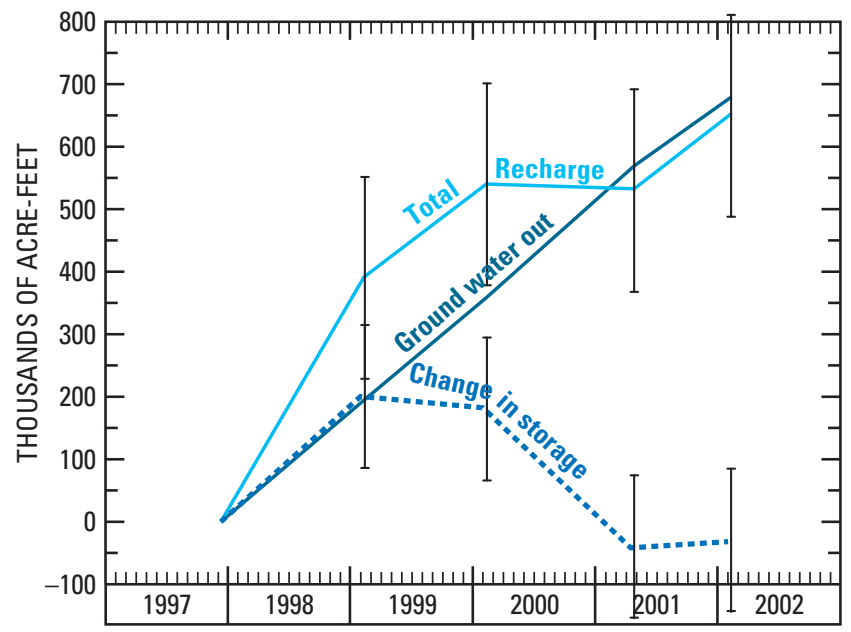

B. Avra Valley

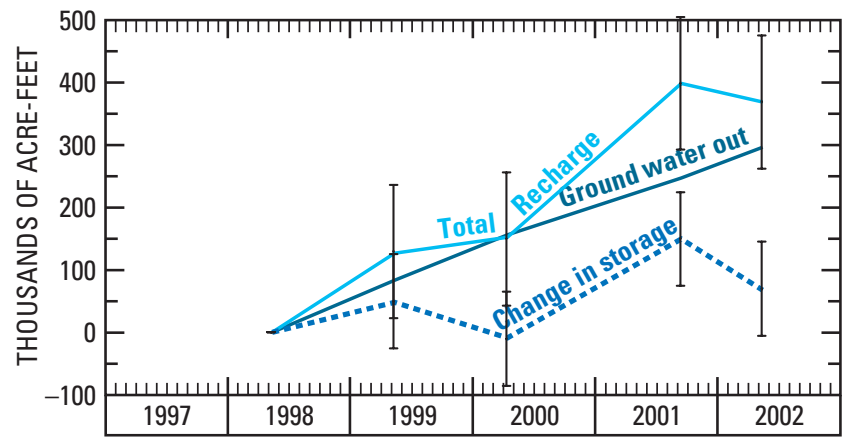

2001 to May 2002 (table 3) are within the range of error of the estimate. Natural recharge averaged 30,000 acre-ft per year, assuming that under sampling of storage change was minimal.

\section{Tucson Active Management Area}

Ground-water budgets for the monitored regions in Tucson Basin and Avra Valley were combined to provide water budgets for a large portion of the TAMA. The monitored regions include about 85 percent of the aquifer extent simulated by a ground-water flow model (Mason and Bota, 2006). A slight increase in storage, 40,000 acre-ft, remained in the monitored region at the end of the monitoring period (table 3 , fig. 10). An increase in storage of 250,000 acre-ft that occurred from December 1997 to May 1999 was sufficient to maintain a positive water balance for the monitored period. From February 1999 to May 2002, the average-annual storage loss was 70,000 acre-ft. Ground-water withdrawals and outflow averaged about 240,000 acre-ft per year during the monitoring period. Average-annual artificial and incidental recharge was about 80,000 acre-ft. Estimated natural recharge was 460,000 acre-ft from

\section{Tucson Active Management Area}

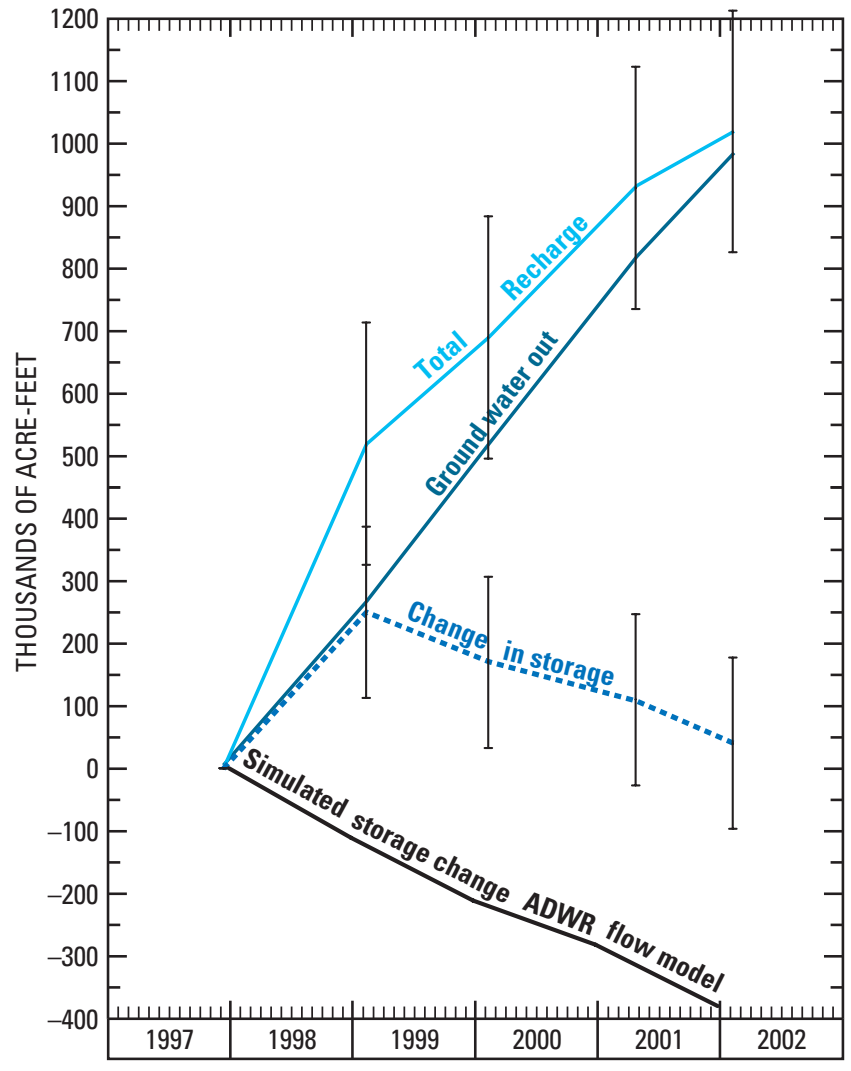

Figure 10. Cumulative ground-water budget within the monitored portions of the: $A$, Tucson Basin; $B$, Avra Valley; and $C$, Tucson Active Management Area, winter 1998 to spring 2002. 
Table 3. Cumulative ground-water budgets for the monitored portions of the Tucson Basin, Avra Valley, and Tucson Active Management Area, 1998 to 2002.

\begin{tabular}{|c|c|c|c|c|c|c|c|}
\hline \multirow[t]{2}{*}{$\begin{array}{c}\text { Regional Monitoring } \\
\text { Network }\end{array}$} & \multirow[t]{2}{*}{$\begin{array}{l}\text { Year of gravity } \\
\text { survey }\end{array}$} & \multirow[t]{2}{*}{$\begin{array}{l}\text { Month of } \\
\text { Survey }\end{array}$} & $\Delta \mathbf{S}$ & $\mathbf{G W}_{\text {out }}$ & $\begin{array}{l}\text { Natural } \\
\text { Recharge }\end{array}$ & $\begin{array}{l}\text { Artificial and } \\
\text { Incidental } \\
\text { Recharge }\end{array}$ & $\begin{array}{c}\text { Total } \\
\text { Recharge }\end{array}$ \\
\hline & & & \multicolumn{5}{|c|}{ (thousands of acre-feet) } \\
\hline \multicolumn{8}{|l|}{ Tucson Basin } \\
\hline & 1998 & Dec-97 & 0 & 0 & 0 & 0 & 0 \\
\hline & 1999 & Feb-99 & 200 & 190 & 380 & 10 & 390 \\
\hline & 2000 & Feb-00 & 180 & 360 & 520 & 20 & 540 \\
\hline & 2001 & May-01 & -40 & 570 & 490 & 40 & 530 \\
\hline & 2002 & Feb-02 & -30 & 680 & 590 & 60 & 650 \\
\hline & $\begin{array}{c}\text { Average Annual } \\
(1998-02)\end{array}$ & & -10 & 160 & 140 & 10 & 150 \\
\hline & $\begin{array}{c}\text { Average Annual } \\
(1999-02)\end{array}$ & & -80 & 160 & 70 & 20 & 90 \\
\hline \multicolumn{8}{|l|}{ Avra Valley } \\
\hline \multirow{7}{*}{\multicolumn{8}{|c|}{$\begin{array}{c}\text { Tucson Active } \\
\text { Management Area }\end{array}$}} \\
\hline & & & & & & & \\
\hline & & & & & & & \\
\hline & & & & & & & \\
\hline & & & & & & & \\
\hline & & & & & & & \\
\hline & & & & & & & \\
\hline & 1998 & $\begin{array}{r}\text { Dec.1997 to } \\
\text { May } 1998\end{array}$ & 0 & 0 & 0 & 0 & 0 \\
\hline & 1999 & $\begin{array}{r}\text { Feb. } 1999 \text { to } \\
\text { May } 1999\end{array}$ & 250 & 270 & 460 & 60 & 520 \\
\hline & 2000 & $\begin{array}{l}\text { Feb. } 2000 \text { to } \\
\text { Apr. } 2000\end{array}$ & 170 & 520 & 570 & 120 & 690 \\
\hline & 2001 & $\begin{array}{l}\text { May } 2001 \text { to } \\
\text { Sep. } 2001\end{array}$ & 110 & 820 & 680 & 250 & 930 \\
\hline & 2002 & $\begin{array}{r}\text { Feb. } 2002 \text { to } \\
\text { May } 2002\end{array}$ & 40 & 980 & 700 & 320 & 1,020 \\
\hline & $\begin{array}{c}\text { Average Annual } \\
(1998-02)\end{array}$ & & 10 & 240 & 170 & 80 & 250 \\
\hline & $\begin{array}{c}\text { Average Annual } \\
\quad(1999-02)\end{array}$ & & -70 & 240 & 80 & 90 & 170 \\
\hline
\end{tabular}


December 1997 to May 1999 followed by an average of 80,000 acre-ft per year from February 1999 to May 2002.

The observed trend in storage loss was similar to the trend simulated by Mason and Bota (2006), with the exception of the increase in storage from December 1997 to May 1999 (fig. 10) that resulted from above average recharge rates during the winter of 1998. The primary difference between estimated and simulated storage change is that naturally variable recharge rates were not included in the simulation. Storage loss in the monitored region from 1999 to 2002, including about 85 percent of the modeled region, was about 80 percent of the value simulated by the ground-water flow model, which suggests that the estimated and simulated average-annual conditions are in close agreement for the period. Investigations of variations in recharge rates in the area (Pool, 2005) suggest that much of the average-annual recharge occurs from significant, large periodic-recharge events that are related to climate variation. In particular, the El Niño Southern Oscillation is significantly correlated with periodic recharge. Ground-water flow models of the region may be improved by inclusion of periodic climate-related variations in recharge.

\section{Summary}

Gravity and land subsidence were monitored annually at wells and benchmarks within two networks in the Tucson Active Management Area during 1998-2002. The monitoring resulted in annual estimates of ground-water storage change, land-subsidence, specific yield, and ground-water budgets for the monitored regions within Tucson Basin and Avra Valley. Significant land-subsidence of more than $1 \mathrm{in}$. occurred only in the central part of Tucson Basin during the monitoring period. Above average recharge during 1998 resulted in changes in ground-water storage and water levels from the monitoring period. Recharge from 1998 was greater than net ground-water withdrawals for the monitored period and was sufficient to maintain a positive water balance. Changes from 1999 to 2002 primarily resulted from ground-water pumpage, redistribution of water that recharged during the previous year, and recharge near artificial-recharge facilities.

Correlations of gravity-based estimates of storage change and water levels at 37 wells were variable and illustrate the complex nature of the aquifer system and the influence of well construction on water levels. Poor and moderate correlation of storage and water-level change occurred at many wells where variations in gravity and water-levels were insufficient for good correlation. Estimated Sy values averaged 0.27 at 10 wells where correlations were good-corre- lation coefficient greater than 0.75 -and stations were not near major ephemeral channels where streamflow infiltration results in unsaturated-zone storage change and perched aquifers. Water levels in several wells likely represent confined ground-water conditions on the basis of large water-level change that were accompanied by little change in storage. Significant changes in unsaturated-zone storage, perched aquifers, or unmonitored unconfined aquifers are suggested by a few sites where water-level changes were small, but large changes in storage were observed. The variable correlation of storage and water-level change indicates that overall changes in aquifer-system storage are difficult to estimate on the basis of water-level change.

Ground-water budget analysis indicates that most of the recharge during the monitoring period in Tucson Basin occurred as a result of above-average precipitation and streamflow infiltration during the winter 1998. Natural recharge varied from 380,000 acre-ft during the initial period to an average rate of 70,000 acre-ft/yr from February 1999 to February 2002. Recharge in Avra Valley was dominated by artificial recharge at several facilities, recharge of infiltrated streamflow, and incidental recharge of effluent along the Santa Cruz River. The distribution of storage change near artificial-recharge facilities near Marana was undersampled by the distribution of monitoring stations and probably resulted in overestimation of storage increases across the local region. A densified network of more closely spaced stations is needed to define storage change near artificialrecharge facilities in Avra Valley. Natural recharge averaged about 30,000 acre-ft/yr in Avra Valley, assuming that undersampling of storage change near artificial-recharge facilities did not significantly bias results for the entire network.

The combined ground-water budgets of Tucson Basin and Avra Valley monitoring networks include a large portion of the TAMA. The water-budget for monitored region of the TAMA was dominated by about 460,000 acre-ft of recharge during 1998 followed by an average-annual recharge rate of about 80,000 acre-ft from 1999 to 2002. The observed storage change in the monitored region compares closely with results of a ground-water flow model (Mason and Bota, 2006) with the exception of the 1998 period of above-average recharge and increased ground-water storage. Storage loss in the monitored region, including about 85 percent of the modeled region, from 1999 to 2002 was about 80 percent of the value simulated by the ground-water flow model. The observed and simulated trends deviate for the period 1998 to 1999 because the model simulated an average-annual rate of recharge rather than a variable recharge rate. Ground-water flow models of the region may be improved by inclusion of periodic climate-related variations in recharge. 


\section{References Cited}

Anderson, S.R., 1989a, Potential for aquifer-system compaction, land subsidence, and earth fissures in the Tucson basin, Pima County, Arizona: U.S. Geological Survey Hydrologic Atlas HA-713, 3 sheets.

Anderson, S.R., 1989b, Potential for aquifer-system compaction, land subsidence, and earth fissures in Avra Valley, Pima and Pinal Counties, Arizona: U.S. Geological Survey Hydrologic Atlas HA-718, 3 sheets.

Buckley, Sean, 2002, unpublished interferograms completed in cooperation with the Arizona Department of Water Resources, Austin, University of Texas.

de Marsily, Ghislain, 1986, Quantitative hydrogeology: San Diego, California, Academic Press, 440 p.

Evans, D.W., and Pool, D.R., 2000, Aquifer compaction and ground-water levels in south-central, Arizona: U.S. Geological Survey Water-Resources Investigations Report 99-4249, 54 p.

Freeze, R. A., and Cherry, J.A., 1979, Groundwater: Englewood Cliffs, New Jersey, Prentice-Hall, Inc., 604 p.

Hanson, R.T., Anderson, S.R., and Pool, D.R., 1990, Simulation of ground-water flow and potential land subsidence, Avra Valley, Arizona: U.S. Geological Survey WaterResources Investigations Report 90-4178, 41 p.

Hanson, R.T., and Benedict, J.F., 1994, Simulation of groundwater flow and potential land subsidence, Upper Santa Cruz Basin, Arizona: U.S. Geological Survey Water-Resources Investigations Report 93-4196, 47 p.

Howle, J.F., Phillips, S.P., Denlinger, R.P., and Metzger, L.F., 2003, Determination of specific yield and water table changes using temporal microgravity surveys collected during the second injection storage and recovery test at Lancaster, California, November through April 1997: U.S. Geological Survey Water-Resources Investigations Report 03-4019, 28 p.

Leenhouts, J.M., Stromberg, J.C., and Scott, R.L., 2006, Hydrologic requirements of consumptive ground-water use by riparian vegetation along the San Pedro River, Arizona: U.S. Geological Survey Scientific Investigations Report 2005-5163, 154 p.
Longman, I.M., 1959, Formulas for computing the tidal acceleration due the moon and sun: Journal of Geophysical Research, v. 64, no. 12, p. 2351-2355.

Mason, D.A., and Bota, Liciniu, 2006, Regional groundwater flow model of the Tucson Active Management Area Tucson, Arizona-Simulation and Application: Arizona Department of Water Resources Modeling Report No. 13, 160 p.

Pool, D.R., 1999, Aquifer-storage change in the Lower Cañada del Oro subbasin, Pima County, Arizona, 1996-98: U.S. Geological Survey Water-Resources Investigations Report 99-4067, 3 sheets.

Pool, D.R., 2005, Variations in climate and natural recharge in Southeast Arizona: Water Resour. Res., 41, W11403, doi:10.1029/2004WR003255, 24 p.

Pool, D.R., and Eychaner, James, 1995, Measurements of aquifer-storage change and specific yield using gravity surveys: Ground Water, v. 33, no. 3, p. 425-432.

Pool, D.R., and Schmidt, Werner, 1997, Measurements of ground-water storage change and specific yield using the temporal gravity method near Rillito Creek, Tucson, Arizona: U.S. Geological Survey Water Resources Investigations Report 97-4125, 30 p.

Pool, D.R., Winester, Daniel, and Cole, K.C., 2000, Land subsidence and ground-water storage monitoring in the Tucson Active Management Area, Arizona: U.S. Geological Survey Fact Sheet 84-00, 4 p.

Stonestrom, D.A., Constantz, J., Ferré, T.P.A., and Leake, S.A., eds., 2008, Ground-water recharge in the arid and semiarid Southwestern United States: U.S. Geological Survey Professional Paper 1703, 427 p.

Strange, W.E., 1983, Subsidence monitoring for the State of Arizona: National Oceanic and Atmospheric Administration report, 74 p.Telford, W.M., Geldart, L.P., Sheriff, R.E., and Keys, D.A., 1976, Applied geophysics: Cambridge, England, Cambridge University Press, 860 p.

Telford, W.M., Geldart, L.P., and Sheriff, R.E., 1990, Applied Geophysics, 2nd ed.: Cambridge University Press, 770 p. 
This page left intentionally blank. 
